University of Florida Levin College of Law

UF Law Scholarship Repository

UF Law Faculty Publications

Faculty Scholarship

Spring 1996

\title{
Understanding Mediators' Orientations, Strategies, and Techniques: A Grid for the Perplexed
}

Leonard L. Riskin

University of Florida Levin College of Law, riskinl@law.ufl.edu

Follow this and additional works at: https://scholarship.law.ufl.edu/facultypub

Part of the Dispute Resolution and Arbitration Commons

\section{Recommended Citation}

Leonard L. Riskin, Understanding Mediators' Orientations, Strategies, and Techniques: A Grid for the Perplexed, 1 Harv. Negot. L. Rev. 7 (1996), available at http://scholarship.law.ufl.edu/facultypub/668

This Article is brought to you for free and open access by the Faculty Scholarship at UF Law Scholarship Repository. It has been accepted for inclusion in UF Law Faculty Publications by an authorized administrator of UF Law Scholarship Repository. For more information, please contact kaleita@law.ufl.edu. 


\title{
Understanding Mediators' Orientations, Strategies, and Techniques: A Grid for the Perplexed
}

\author{
Leonard L. Riskin ${ }^{\dagger}$
}

Introduction $\ldots \ldots \ldots \ldots \ldots \ldots \ldots \ldots \ldots \ldots \ldots \ldots \ldots \ldots \ldots, \quad 8$

I. Categories of Negotiation and Mediation ............. 13

II. The Proposed System ........................ 16

A. The Problem-Definition Continuum: Goals, Assumptions, and Focuses................... 18

B. The Mediator's Role: Goals and Assumptions

Along the Facilitative-Evaluative Continuum ...... 23

C. The Four Orientations: Strategies and

Techniques................................. 25

1. Evaluative-Narrow....................... 26

Copyright @ Leonard L. Riskin.

$t$ C.A. Leedy Professor of Law and Director, Center for the Study of Dispute Resolution, University of Missouri-Columbia School of Law.

I developed the principal ideas expressed in this Article as part of a program to train lawyers and their clients in how to participate in mediation. I am especially grateful to John Phillips of Blackwell Sanders Matheny Weary \& Lombardi in Kansas City for inviting me to conduct that program; to my most frequent training colleagues - Deborah Doxsee, Michael Keating, and Charles Wiggins; and to Robert Ackerman, for suggestions and encouragement in the early stages.

Some preliminary thoughts on the topic addressed in this Article appeared in Leonard L. Riskin, Mediator Orientations, Strategies, and Techniques, Alternatives to the High Cost of Litigation, Sept. 1994, at 111. Many thanks to Deborah Jacobs, the editor of Alternatives, who helped clarify my thinking enormously.

I also thank several colleagues for carefully reading and commenting on a draft of this Article: Deborah Doxsee, Michael Keating, Lela Love, Margaret Shaw, and Frank Sander. I have presented versions of the central ideas expressed in this Article at programs sponsored by the Association of American Law Schools; the CPR Institute for Dispute Resolution; the Lex Mundi Global College of Mediators; the Faegre Group; the U.S. District Court for the Eastern District of Missouri; the law firms of Armstrong, Teasdale, Schafly \& Davis and Blackwell Sanders Matheny Weary \& Lombardi; and the Law Schools of the University of Washington and Hamline and Willamette Universities. I gathered valuable insights on each occasion and in response to the Alternatives article. In all, I received too many thoughtful suggestions to acknowledge, but I especially thank Jacqueline Nolan-Haley and Jonathan Hyman. 
2. Facilitative-Narrow ...................... 28

3. Evaluative-Broad ........................ 30

4. Facilitative-Broad....................... 32

D. Movement Along the Continuums and Among the

Quadrants: Limitations on the Descriptive

Capabilities of the Grid ...................... $\quad 35$

III. Effectiveness of the Grid, Especially in Selecting

Mediators..................................... 38

A. The Potential Advantages and Disadvantages of the Various Approaches to Mediation............. 41

1. The Problem-Definition Continuum ........... 42

a. Narrow Problem-Definition ............... 42

b. Broad Problem-Definition.................. 43

2. The Mediator Role Continuum .............. 44

a. The Evaluative Approach ............... 44

b. The Facilitative Approach ............... 45

B. The Importance of Subject-Matter Expertise....... 46

C. The Importance of Impartiality ................ 47

IV. Conclusion ................................ 48

Figures

Figure 1. Problem-Definition Continuum............ 22

Figure 2. Mediator Orientations .................. $\quad 25$

Figure 3. Mediator Techniques................... $\quad 35$

Figure 4. Grid with N.W. \& S.E. Corners Removed .... 50

Figure 5. Grid Showing Core and Periphery of Mediation Practices..................... $\quad 51$

\section{INTRODUCTION}

Not long ago, a lawyer asked me to conduct a workshop, for his firm and its clients, on how to participate in a mediation. As I began to prepare this program, I realized that my co-trainers and I could not talk sensibly about how, or even whether, to participate in a mediation without knowing the nature of the process the mediator would conduct. But a bewildering variety of activities fall within the broad, generally-accepted definition of mediation - a process in which an impartial third party, who lacks authority to impose a solution, helps others resolve a dispute or plan a transaction. Some of these processes have little in common with one another. And there is no comprehensive or widely-accepted system for identifying, describing, or classifying them. Yet most commentators, as well as mediators, lawyers, and others familiar with mediation, have a definite image of what mediation is and should be. 
For these reasons, almost every conversation about mediation suffers from ambiguity, a confusion of the "is" and the "ought." This creates great difficulties when people try to determine whether and how to participate in mediation, and when they grapple with how to select, train, evaluate, or regulate mediators.

The largest cloud of confusion and contention surrounds the issue of whether a mediator may evaluate. "Effective mediation," claims lawyer-mediator Gerald S. Clay, "almost always requires some analysis of the strengths and weaknesses of each party's position should the dispute be arbitrated or litigated." But law school Dean James Alfini disagrees, arguing that "lawyer-mediators should be prohibited from offering legal advice or evaluations. ${ }^{2}$ Formal ethical standards have spoken neither clearly nor consistently on this issue. ${ }^{3}$

1. James Alfini \& Gerald S. Clay, Should Lawyer-Mediators Be Prohibited from Providing Legal Advice or Evaluations?, DisP. Resol. MAa., Spring 1994, at 8.

2. Id. Professor Robert A. Baruch Bush agrees with Alfini. See Robert A.B. Bush, The Dilemmas of Mediation Practice: A Study of Ethical Dilemmas and Policy Implications, 1994 J. Disp. Resol. 1, 54 (1994).

3. Several such standards seem to limit evaluative activity in the name of selfdetermination. For example, a Code of Professional Conduct adopted by the Colorado Council of Mediation Organizations in 1982 describes the mediator as an "active resource person" who "should be prepared to provide both procedural and substantive suggestions and alternatives ...." Colorado CouncIL of MEdiation OrGanizations, Code of Professional Conduct \& 2 (1982), reprinted in Kmberlee K. Kovach, MEdiation: Principles and Practice 260, 261 (1994). But it cautions that "[s]ince the status, experience and ability of the mediator lend weight to his or her suggestions and recommendations, the mediator should evaluate carefully the effect of interventions or proposals and accept full responsibility for their honesty and merit." Id.

Ethical Guidelines adopted in 1994 by the Alternative Dispute Resolution Section of the State Bar of Texas emphasize self-determination and provide that the mediator "should not coerce a party in any way." Alternative Dispute Resolution Section, State Bar of Texas, Ethical Gumelines for Mídiators § 1, cmt. A (1994). The mediator "may make suggestions," id., but "should not give legal or other professional advice," $i d$. at $\S 11$. The question whether a mediator may evaluate caused much dissension among members of a joint committee on standards of conduct for mediators established by the American Arbitration Association, the American Bar Association, and the Society of Professionals in Dispute Resolution. The group ultimately compromised, using the following language intended to discourage evaluative activities by the mediator:

The primary purpose of a mediator is to facilitate the parties' voluntary agreement. This role differs substantially from other professional-client relationships. Mixing the role of a mediator and the role of a professional advising a client is problematic and mediators must strive to distinguish between the roles. A mediator should therefore refrain from providing professional advice. Where appropriate, a mediator should recommend that the parties seek outside professional advice, or consider resolving the dispute through arbitration, counselling, neutral evaluation, or other processes. A mediator 
Other issues also bedevil the mediation field. People of good will argue about whether mediation should be employed in cases involving constitutional rights, ${ }^{4}$ domestic violence, ${ }^{5}$ or criminal activity. ${ }^{6}$

who undertakes, at the request of the parties, an additional dispute resolution role in the same matter assumes increased responsibilities and obligations that may be governed by the standards of other professions.

Standards OF CoNdUCT FOR MEdiators (American Arbitration Association, Society of Professionals in Dispute Resolution, and American Bar Association Section on Dispute Resolution, 1994). According to Dean James Alfini, a member of the joint committee that prepared this language, he and some other members of the committee were concerned that if lawyer-mediators were to give legal evaluations, regulatory bodies in the profession might consider mediation as the practice of law and, therefore, seek to regulate, control, or proscribe it. Telephone interview with James Alfini, Dean of Northern Illinois University College of Law (Jan. 24, 1995).

One set of standards seems to endorse evaluations, except in one limited circumstance. The Florida Rules for Certified and Court-Appointed Mediators emphasize self-determination and prohibit coercion. See FlA. R. FOR CERTIFIEd \& CourT-AP. POINTED MEDIATORs Rule 10.060 (1992). A committee note provides that "[w]hile a mediator has no duty to specifically advise a party as to the legal ramifications or consequences of a proposed agreement, there is a duty for the mediator to advise the parties of the importance of understanding such matters and giving them the opportunity to seek such advice if they desire." Id. (Committee note). Another rule, however, bars the mediator from offering "a personal or professional opinion as to how a court in which the case has been filed will resolve the dispute." Id. at 10.090. Professor Robert Moberly, a member of the drafting committee, explains that this language is meant to "prohibit tactics that imply some special knowledge of how a particular judge will rule." Robert B. Moberly, Ethical Standards for Court-Appointed Mediators and Florida's Mandatory Mediation Experiment, 21 FLA. ST. U. L. REV. 701, 715 (1994).

The ABA's Standards of Practice for Lawyer Mediators in Family Disputes treat this issue in connection with the duty it imposes on the mediator "to assume that the mediation participants make decisions based upon sufficient information and knowledge." American Bar Association, Standards of Practice for Lawyer Mediators IN Family Disputes, Standard IV (1984). A "specific consideration" provides that "[ $t]$ he mediator may define the legal issues, but shall not direct the decision of the mediation participants based upon the mediator's interpretation of the law as applied to the facts of the situation." Id. at Specific Consideration C.

4. See Owen Fiss, Against Settlement, 93 Yale L.J. 1073, 1082-87 (1984); Owen Fiss, Out of Eden, 94 YALE L.J. 1669 (1985); Andrew W. McThenia \& Thomas L. Shaffer, For Reconciliation, 94 YALE L.J. 1660 (1985).

5. See Trina Grillo, The Mediation Alternative: Process Dangers for Women, 100 YALE L.J. 1545 (1991); Joshua D. Rosenberg, In Defense of Mediation, 33 ARIZ. L. REv. 467 (1991).

6. Compare, e.g., Albert Alschuler, Mediation with a Mugger: The Shortage of Adjudicative Services and the Need for a Two.Tier Trial System in Civil Cases, 99 Harv. L. Rev. 1808, 1808-10 (1986) with Mark S. Umbreit, Victim MeEts Offender: The Impact of Restorative Justice and Mediation (1994). 
Program planners differ on how to select mediators. ${ }^{7}$ Trainers disagree on the place of the private caucus. ${ }^{8}$ Commentators debate whether the mediator should bear responsibility for the outcome of environmental mediation..$^{9}$ Lawyers and judges argue about whether a judge may order a represented client to attend a settlement conference along with her or his lawyer. ${ }^{10}$ Disputants selecting a mediator worry about bias and whether the neutral should have "subject-matter expertise."11 And many lawyers and clients wonder about what exactly mediation is and how it differs from other dispute resolution processes.

The bulk of these disagreements arise out of clashing assumptions - often unarticulated - about the nature and goals of mediation. ${ }^{12}$ Nearly everyone would agree that mediation is a process in which an impartial third party helps others resolve a dispute or plan a transaction. Yet in real mediations, goals and methods vary so greatly that generalization becomes misleading. This is not simply because mediators practice differently according to the type of dispute or transaction; even within a particular field, one finds a wide range of practices. For example, in studying farm-credit mediation, I discerned two patterns of mediation, which I called "broad" and "narrow." ${ }^{13}$ These patterns differed so radically that they could both be

7. See The Test Design Project, Perfornance-Based Assessment: A Metr. odology for Use in Selicting, Training, and Evazuating Mídiators (National Institute for Dispute Resolution ed., 1995); Who Really is a Mediator?, 9 NEG. J. 293 (1993).

8. See Carrie Menkel-Meadow, Ex Parte Talks with Neutrals: ADR Hazards, An ternatives to the High Cost of Litigation, Sept. 1994, at 1.

9. See John P. McCrory, Environmental Mediation - Another Piece for the Puzzle, 6 VT. L. Rev. 49, 64 (1981); Joseph B. Stulberg, The Theory and Practice of Mediation: A Reply to Professor Susskind, 6 VT. L. REv. 85, 106 (1981); Lawrence Susskind, Environmental Mediation and the Accountability Problem, 6 VT. L. REv. 1, 40 (1981).

10. See Leonard L. Riskin, The Represented Client in a Settlement Conference: The Lessons of G. Heileman Brewing Co. v. Joseph Oat Corp., 69 WASH. U. L.Q. 1059 (1991).

11. See infra note 123 and accompanying text.

12. See Robert A.B. Bush, Mixed Messages in the Interim Guidelines, 9 NEG. J. 341 (1993); Craig A. McEwen, Competence and Quality, 9 NEG. J. 317 (1993); Richard A. Salem, The Interim Guidelines Need a Broader Perspective, 9 NEG. J. 309 (1993); Joseph B. Stulberg, Bush on Mediator Dilemmas, 1994 J. DisP. Resol. 57 (1994). A useful effort to clarify these assumptions appears in Robert A.B. Bush, The Mediator's Role and Ethical Standards in Mediation, 41 U. FLA. L. REv. 253 (1989). See also Riskin, supra note 10.

13. See Leonard L. Riskin, Two Concepts of Mediation in the FaIHA'S FarmerLender Mediation Program, 45 AdMIn. L. REv. 21, 44-55 (1993). 
called mediation only in the sense that noon meals at McDonald's and at Sardi's could both be called lunch. ${ }^{14}$

The confusion is especially pernicious because many people do not recognize it; they describe one form of mediation and ignore other forms, ${ }^{15}$ or they claim that such forms do not truly constitute mediation. ${ }^{16}$ I do not aim in this Article to favor one type of mediation over

14. Similar confusion doubtless afflicts other dispute resolution processes. In their study of the early neutral evaluation program of the U.S. District Court for the Northern District of California, for example, Professor Joshua Rosenberg and Dean Jay Folberg found:

The ENE process was intended to lie somewhere between mediation, in which a third party with substantial procedural expertise facilitates communication among the parties in the interest of settling some or all of the issues in dispute, and nonbinding arbitration, in which a third party with substantial subject matter expertise reviews the case presented by the litigants and determines an appropriate outcome. As conducted, ENE ran the gamut from one extreme to the other, and sometimes bore little resemblance to any other process. Most evaluators appraised their cases in some respects, but the specificity and directness of these appraisals varied tremendously from actual predictions of jury verdicts to subtle hints about possible weaknesses of a claim or defense.

Joshua D. Rosenberg \& H. Jay Folberg, Alternative Dispute Resolution: An Empirical Analysis, 46 STAN. L. REv. 1487, 1496 (1994).

15. See, e.g., Susan S. Silbey, Mediation Mythology, 9 NEG. J. 349 (1993). Proponents of particular mediation orientations sometimes appear to show disdain for other orientations. Consider, for example, the opinion of Richard Ralston, a lawyer-mediator based in Kansas City who has extensive experience as a trial lawyer and as a U.S. Magistrate-Judge:

You must define the qualities desired in a mediation in light of what is to be accomplished. Some mediators will not give an opinion or an evaluation, but an effective mediator is not a "potted plant," who simply carries messages back and forth. The mediator should have a reputation for neutrality, judgment, fairness, balance and creativity. Credibility is the key. If the parties respect the mediator, a large barrier to effective negotiation is removed. Most parties who are serious about resolving the dispute will choose a mediator who can give a strong, credible and objective evaluation of the legal and factual issues in the case. A good mediator is a blend of psychotherapist, judge and negotiator who can recognize the motivations of the parties (Is it only money, or is it something else?). An effective mediator is not "Mr. Rog. ers." Most parties who truly desire a negotiated resolution of the dispute will choose a mediator who can give a strong, objective evaluation of the case and who can "close" the negotiations. Experience and effectiveness in mediation is a primary consideration in choosing a mediator.

Richard H. Ralston, Effective Advocacy and Mediation, in ADR FOR THE DEFENSE: AL ternative Dispute Resolution (Defense Research Institute, Inc., 1994) H-1, at H-3 (emphasis added).

16. See Stulberg, supra note 9; Austin Sarat, Patrick Phear: Control, Commitment, and Minor Miracles in Family and Divorce Mediation, in WHEN TALK WORKS 193, 195-96 (Deborah M. Kolb ed., 1994). 
another, although, like most mediators, I incline toward a certain approach. ${ }^{17}$ Instead, I hope to facilitate discussions and to help clarify arguments by providing a system for categorizing and understanding approaches to mediation. I try to include in my system most activities that are commonly called mediation and arguably fall within the broad definition of the term. I know that some mediators object to such inclusiveness, and fear that somehow it will legitimize activities that are inconsistent with the goals that they associate with mediation. ${ }^{18}$ Although I sympathize with this view, I also disagree with it. Usage determines meaning. ${ }^{19}$ It is too late for commentators or mediation organizations to tell practitioners who are widely recognized as mediators that they are not, in the same sense that it is too late for the Pizza Association of Naples, Italy to tell Domino's that its product is not the genuine article. ${ }^{20}$ Such an effort would both cause acrimony and increase the confusion that I am trying to diminish. Instead, I propose that we try to categorize the various approaches to mediation so that we can better understand and choose among them.

Part I of this Article sets forth previous efforts to categorize mediation. Although each of these served a particular purpose, none was designed for comprehensive use. My system for classifying mediator orientations, strategies, and techniques - which I depict by means of a grid - makes up Part II. Part III describes the utility of the grid, especially in selecting mediators. Part IV is the conclusion.

\section{Categories of Negotiation and Mediation}

Mediation is facilitated negotiation, and most commentators recognize two basic approaches to negotiation. Of the many dichotomies developed, ${ }^{21}$ I find "adversarial" versus "problem-solving" the most

17. I tend to favor what I describe in Part II.C.4 as the facilitative-broad approach. See, e.g., Leonard L. Riskin, Mediation and Lawyers, 43 Omo Sr. L.J. 29 (1982); Riskin, supra note 13. However, this does not keep me from seeing the virtues of other approaches in appropriate cases.

18. Memorandum from Lela P. Love to Leonard L. Riskin (April 3, 1995).

19. See Ludimg Wittgenstein, Tractatus Logico - Phmosophicus 9-25 (D.F. Pears \& B.F. McGuinness trans., 2d ed. 1974).

20. See Florence Fabricant, The Italian Pizzo Police Are Offering Rules for the Real Thing, N.Y. Trmes, June 7, 1995, at C6; The Pizza Police Get Tough, N.Y. Thres, June 7, 1995, at C1.

21. See, e.g., David A. Lax \& James K Sebenius, The Mlanager as Negotiator 29-45, 88-153 (1986) (distinguishing bargaining to "create value" and to "claim value"); Howard Raiffa, The Aft and Science of Negotiation 33-34 (1982) (distinguishing "distributive" and "integrative" bargaining); RICHARD E. WALTON \& ROBERT B. McKersie, A Behavioral Theory of Labor Negotiations 4-5, 11-183 (2d ed. 1991) (exploring differences between "distributive" and "integrative" bargaining); Gary T. Lowenthal, A General Theory of Negotiation Process, Strategy, and Behavior, 
generally useful. ${ }^{22}$ The adversarial approach usually assumes that the negotiation will focus on a limited resource - such as money and that the parties will decide whether and how to divide it. In such a situation, the parties' goals conflict - what one gains, the other must lose. ${ }^{23}$ The problem-solving approach, in contrast, seeks to bring out and meet the underlying interests of the parties - i.e., the needs that motivate their positions. ${ }^{24}$ Unfortunately, negotiators generally face a tension between adversarial and problem-solving approaches, as each tends to interfere with the other. ${ }^{25}$

Some commentators have seized on this distinction as a basis for categorizing approaches to mediation, ${ }^{26}$ but many writers have seen things differently, and numerous systems of categorizing mediation

31 U. KAN. L. REv. 69, 73-92 (1982) (distinguishing "competition" from "collaboration").

Some commentators have divided negotiation into three types. See, e.g., Roger Fisher ET AL., GETTING to YES 9-14 (2d ed. 1991) (differentiating "hard," "soft," and "principled" styles of negotiation); Donald G. Gifford, LEgal NEGotiation 14-18 (1989) (identifying "cooperative," "competitive," and "integrative" strategies). See generally, Leonard L. Riskin \& James E. Westbrook, Dispute Resolution And Law. YERS 115-38 (1987) (reviewing these approaches and alternative views of negotiation strategy).

22. See Carrie Menkel-Meadow, Toward Another View of Legal Negotiation: The Structure of Problem-Solving, 31 UCLA L. REv. 754, 755-62 (1984).

23. An adversarial orientation naturally fosters strategies designed to maximize a party's position with respect to the resource in question. The usual tactics, designed to uncover as much as possible about the other side's situation and simultaneously to mislead the other side about yours, include:

1. A high initial demand;

2. Limited disclosure of information about facts and one's own preferences;

3. Few and small concessions;

4. Threats and arguments; and

5. Apparent commitment to positions during the negotiation process.

See Donald G. Gifford, A Context-Based Theory of Strategy Selection in Legal Negotiation, 46 Oнто Sт. L.J. 41, 48-49 (1985).

24. The most popular articulation of a problem-solving orientation is FISHER ET AL., supra note 21 . The authors set out four guidelines for what they call "principled" negotiation:

1. Separate the people from the problem.

2. Focus on interests, not positions.

3. Invent options for mutual gain.

4. Insist on objective criteria.

See id. at 15. Related books include Roger Frsher \& ScotT Brown, Getring To. Gether (1988); William URy, GetTing Past No (rev. ed. 1993).

25. See Lax \& Sebenius, supra note 21, at 34-35.

26. For example, Kressel and his colleagues identified the "settlement-oriented style" and the "problem-solving style" when studying custody mediation in a Now Jersey family court. See Kenneth Kressel et al., The Settlement-Orientation vs. The Problem-Solving Style in Custody Mediation, J. Soc. Issues 67 (1994). Employing different terminology, I relied on the same dichotomy in analyzing judicially-hosted settlement conferences. See Riskin, supra note 10, at 1081. Recently, Professor 
have blossomed. Generally, the categories evolved from observations of mediation in a particular context and they enhanced the authors' abilities to understand and describe mediation practices. ${ }^{27}$ Individual authors have constructed different systems of categories for different contexts and for different purposes.28 Sometimes the

Jonathan Hyman and his colleagues, in observing judicially-hosted settlement conferences in New Jersey, developed a dichotomy of styles which they called "mini-trial" and "matchmaker." Jonathan M. HyMan et al., Civil SetTlearent: Strues of Nego. tiation in Dispute Resolution, A Report for the New Jersey Office of the CourTs (1995).

27. For example, in studying programs that mediated family, community and neighborhood disputes, social scientists Susan Silbey and Sally Merry developed two "ideal types," representing what they called the "bargaining" and the "therapeutic" styles. See Susan S. Silbey \& Sally E. Merry, Mediator Settlement Strategies, 8 LAw \& PoL'y 7, 19 (1986) (suggesting that mediators' behavior fell along a continuum with these two styles representing the poles). Texas lawyer-mediator Eric Galton, in teaching lawyers how to use mediation in cases moving through the litigation process, distinguished between "case evaluation," or "evaluative mediation," and "pure form mediation.” Eric Galton, Representing Clients in Mediation 2-4 (1994). Galton writes that "empowerment mediation" and "community model mediation" are synonymous with "pure form mediation." Id. at 3.

See also James Alfini, Trashing, Bashing, and Hashing It Out: Is This the End of "Good Mediation"?, 19 FLA. ST. U. L. REv. 47, 66-73 (1991) (exploring "trashing," "bashing" and "hashing" strategies used in court-connected mediations in Florida); Peter J.D. Carnevale, Strategic Choice in Mediation, 2 NEG. J. 41, 44-45 (1986) Clabelling a mediator's four basic strategies as "integration," "pressing," "compensation," and "inaction").

28. For example, in her study of labor mediators, Deborah Kolb found two patterns: state mediators were "dealmakers" who constructed settlement proposals, and federal mediators were "orchestrators" who helped the parties develop their own proposals. See Deborah M. Kolb, The Mediators $23-45$ (1983). More recently, Professor Kolb and Professor Kenneth Kressel developed different categories with which to view the work of the twelve mediators - operating in a wide range of fields - who were profiled in the book, WHEN TAIK Works. See supra note 16, at 459-92. Kolb and Kressel determined that the mediators espoused either a "transformative" vision or a "pragmatic, problem-solving" vision and that the mediators organized their work through either a "settlement frame" or a "communication frame." See id. at 459, 466-79.

Kressel also has employed other categories in other contexts. In studying custody mediation in a New Jersey family court, he and his colleagues identified the "settlement-oriented style" and the "problem-solving style." See Kressel et al., supra note 26. In another work, Kressel and Pruitt developed a different dichotomy - "taskoriented" versus "socioeconomic." See Kenneth Kressel \& Dean G. Pruitr, MEdiation Research: The Process and Effectiveness of Third-Party Intervention 423-24 (1989).

I, too, have used different systems for different purposes. In studying farm-credit mediation, I developed a "broad-narrow" scheme. See Riskin, supro note 13, at 44. However, when I considered the question of how clients should participate in judicially-hosted settlement conferences, I thought it was important to distinguish the conduct of the judicial host based on two criteria: (1) the extent to which she facilitates adversarial as opposed to problem-solving negotiation; and (2) the extent to which she "raises a fist to pressure the parties to settle or extends a hand to facilitate 
categories have helped the authors argue for a particular kind of mediation, either in a certain context or more generally. ${ }^{29}$

Each of these systems of categories served its author's purposes, yet the categories are not wholly consistent from one system to the other. ${ }^{30}$ Moreover, a specific term can carry different meanings in different systems. ${ }^{31}$ None of these systems were designed to be used comprehensively - that is, to describe orientations, strategies, and techniques employed in virtually any mediation context. ${ }^{32}$ In the next part of this Article, I offer such a system. ${ }^{33}$

an educational process that will enable the parties to learn and do what they must in order to reach a settlement decision." Riskin, supra note 10, at 1083.

29. Kressel and his colleagues have touted the virtues of the "problem-solving" style in custody mediation. See Kressel et al., supra note 26, at 82 . I have argued for a "broad" approach, as opposed to a "narrow" one, in farm-credit mediation. See Riskin, supra note 13, at 60-64. In their recent book, Bush and Folger distinguished as did Kolb and Kressel - between "problem-solving" and "transformative" mediation, urging that the "mediation movement" adopt the latter. See ROBERT A.B. BUSH \& Joseph P. Folger, The Promise of Mediation: Responding to Conflict Through EMPOWERMENT AND RECOGNITION (1994). Mark Umbreit uses a dichotomy of "controlling" and "empowering" styles of mediation in interpersonal disputes, see UMBREIT, supra note 6 , at 34 , and promotes what he calls "humanistic" mediation as way to achieve peace, both outer and inner. See id. at 198-216.

30. However, Kenneth Kressel and Dean Pruitt have created a new dichotomy of styles - "task-oriented" and "socioemotional" - based on a purported consistency among other systems of categorization. See KRESSEL \& PRUITT, supra note 28, at 422-23.

31. For instance, the "problem-solving style" presented by Kressel and his colleagues denotes interest-based negotiation. On the other hand, Bush and Folger generally employ "problem-solving" to include any kind of mediation that emphasizes resolving specific issues in dispute, as opposed to changing, or "transforming," the parties. See BuSh \& FolgER, supra note 29, at 12. At one point, however, Bush and Folger recognize "the advent of an 'adversarial' form of mediation that greatly narrows and adversarializes the process, an approach often associated with mediators who are former judges." Id. at 73. But they add: "It is too soon to tell whether this is in fact a distinct approach or simply an extreme version of problem-solving mediation in which mediator directiveness is even more pronounced." Id.

32. The legal philosopher Felix Cohen wrote, "A definition of law is useful or useless. It is not true or false any more than a New Year's resolution or an insurance policy. A definition is in fact a type of insurance against certain risks of confusion." Felix Cohen, Transcendental Nonsense and the Functional Approach, 35 Colum. L. REv. 809, 835-36 (1935). Cohen's idea applies equally to systems of categorization.

33. I am aware that, although systems of categorization help us understand reality, they also distort it. I am humbled by Robert Benchly's pronouncement that "[t] here may be said to be two classes of people in the world: those who constantly divide the people of the world into two classes, and those who do not." Paul Dickson, The Official Rules, The WASHINGTONIAN, Nov. 1978, at 152. 


\section{The Proposed System}

The system I propose describes mediations by reference to two related characteristics, each of which appears along a continuum. One continuum concerns the goals of the mediation. In other words, it measures the scope of the problem or problems that the mediation seeks to address or resolve. At one end of this continuum sit narrow problems, such as how much one party should pay the other. At the other end lie very broad problems, such as how to improve the conditions in a given community or industry. ${ }^{34}$ In the middle of this continuum are problems of intermediate breadth, ${ }^{35}$ such as how to address the interests of the parties or how to transform the parties involved in the dispute.

The second continuum concerns the mediator's activities. It measures the strategies and techniques that the mediator employs in attempting to address or resolve the problems that comprise the subject matter of the mediation. One end of this continuum contains strategies and techniques that facilitate the parties' negotiation; at the other end lie strategies and techniques intended to evaluate matters that are important to the mediation.

The following hypothetical, developed by Professor Charles Wiggins, will help illustrate the system of categorization that I propose.

\section{COMPUTEC}

Golden State Savings \& Loan NTC is the second largest savings and loan association in the state. Just over a year ago, it contracted with Computec, a computer consulting firm, to organize and computerize its data processing system and to operate that system for a period of ten years. Computec thus became responsible for all of the computer-related activities of

34. A recent report of the Society of Professionals in Dispute Resolution noted the presence in dispute resolution of "conflicting values and goals, including:

1. increased disputant participation and control of the process and outcome

2. restoration of relationships

3. increased efficiency of the judicial system and lowered costs

4. preservation of social order and stability

5. maximization of joint gains

6. fair process

7. fair and stable outcomes and

8. social justice."

Ensuring Competence and Quality in Dispute Resolution Practice, REPORT 2 of THE SPIDR CoMmission on Qualifications 5 (Society of Professionals in Dispute Resolution, 1995).

35. Conceptually, "deep" probably would work as well as "broad," but I find it too difficult to depict graphically. 
the savings and loan, such as account management, loan processing, investment activity, and payroll. Golden State agreed to pay Computec a consulting and administration fee of over one million dollars per year for the term of the contract.

At the end of the first year of operation under this contract, Computec presented Golden State with a bill for approximately $\$ 30,000$ in addition to the agreed-upon fee. This bill represented costs incurred by Computec staff in attending seminars and meetings related to the installation of computer technology in banks, and costs incurred while meeting with various outside consultants on aspects of the contract with Golden State. Upon receipt of this bill, Golden State wrote to Computec, advising Computec that because Golden State could find no express term in the contract requiring reimbursement for these charges, and because the bank had a strict policy against reimbursement for such expenses incurred by its own employees, it would not reimburse Computec staff for similar expenses. Computec responded quickly, informing Golden State that this type of charge was universally reimbursed by the purchaser of computer consulting services, and that it would continue to look to Golden State for reimbursement.

The conflict is generating angry feelings between these two businesses, who must work together closely for a number of years. Neither party can see any way of compromising on the costs already incurred by Computec, and of course Computec expects to be reimbursed for such charges in the future as well. Under applicable law, reasonable expenses directly related to the performance of a professional service contract are recoverable as an implied term of the contract if it is industry practice that they be so paid. It is unclear, however, whether the purchaser of these services must be aware of the industry practice at the time of contracting. ${ }^{36}$

\section{A. The Problem-Definition Continuum: Goals, Assumptions, and Focuses}

The focus of a mediation - its subject matter and the problems or issues it seeks to address - can range from narrow to broad. Here, I identify four "levels" of a mediation that correspond to different degrees of breadth. ${ }^{37}$

36. Copyright $\odot 1985,1996$ Charles B. Wiggins. Reprinted with permission. All rights reserved.

37. I am grateful to Professor Lela Love for suggesting the concept of levels to explain the problem-definition continuum. 


\section{Level I: Litigation Issues}

In very narrow mediations, the primary goal is to settle the matter in dispute though an agreement that approximates the result that would be produced by the likely alternative process, such as a trial, without the delay or expense of using that alternative process. ${ }^{38}$ The most important issue tends to be the likely outcome of litigation. "Level I" mediations, accordingly, focus on the strengths and weaknesses of each side's case.

In a "Level I" mediation of the Computec case, the goal would be to decide how much, if any, of the disputed $\$ 30,000$ Golden State would pay to Computec. The parties would make this decision "in the shadow of the law."39 Discussions would center on the strengths and weaknesses of each side's case and on how the judge or jury would likely determine the relevant issues of fact and law. ${ }^{40}$

\section{Level II: "Business" Interests}

At this level, the mediation would attend to any of a number of issues that a court would probably not reach. The object would be to satisfy business interests. For example, it might be that Golden State is displeased with the overall fee structure or with the quality or quantity of Computec's performance under the contract, and the mediation might address these concerns. Recognizing their mutual interest in maintaining a good working relationship, in part because they are mutually dependent, the companies might make other adjustments to the contract.

Broadening the focus a bit, the mediation might consider more fundamental business interests, such as both firms' need to continue doing business, make profits, and develop and maintain a good reputation. Such a mediation might produce an agreement that, in addition to disposing of the $\$ 30,000$ question, develops a plan to

38. Mediation programs that sponsor narrowly-focused mediations might have closely-related goals, such as saving judicial time and resources. See supra note 34 and accompanying text.

39. See Robert H. Mnookin \& Lewis Kornhauser, Bargaining in the Shadow of the Law: The Case of Divorce, 88 YaLE L.J. 950 (1979).

40. These include: whether the expenses were directly related to the performance of the contract, whether the expenses were reasonable, whether it was industry practice to pay such expenses, and whether, in order for the court to find an implied promise to pay such expenses, the purchaser of the services must have been aware of the industry practice. For a discussion of these issues, see Manakuli Paving \& Rock Co. v. Shell Oil Co., Inc., 664 F.2d 772 (9th Cir. 1981).

Such extremely narrow problem-definitions typify court-ordered arbitration, summary jury trials, early neutral evaluation, and, usually, moderated settlement conferences. 
collaborate on a new business venture. Thus, by exploring their mutual business interests, both companies have the opportunity to improve their situations in ways they might not have considered but for the negotiations prompted by the dispute.

\section{Level III: Personal/Professional/Relational Issues}

"Level III" mediations focus attention on more personal issues and interests. For example, during the development of the $\$ 30,000$ dispute, each firm's executives might have developed animosities toward or felt insulted by executives from the other firm. This animosity might have produced great anxiety or a loss of self-esteem. On a purely instrumental level, such personal reactions can act as barriers to settlement. Although Fisher, Ury and Patton tell us to "separate the people from the problem," ${ }^{11}$ sometimes the people are the problem. Thus, mediation participants often must address the relational and emotional aspects of their interactions in order to pave the way for settlement of the narrower economic issues. In addition, addressing these relational problems may help the parties work together more effectively in carrying out their mediated agreement.

Apart from these instrumental justifications, addressing these personal and relational problems can be valuable in its own right. Focusing on such issues may be important even if the mediation does not produce a solution to the narrower problems. ${ }^{42}$ In other words, a principal goal of mediation could be to give the participants an opportunity to learn or to change. ${ }^{43}$ This could take the form of moral growth or a "transformation," as understood by Bush and Folger to include "empowerment" (a sense of "their own capacity to handle life's problems") and "recognition" (acknowledging or empathizing with others' situations). ${ }^{44}$ In addition, the parties might repair their relationship ${ }^{45}$ by learning to forgive one another ${ }^{46}$ or by recognizing

41. See Fisher ET AL., supra note 21, at 17-39.

42. See Bush \& Folger, supra note 29 passim; Lon L. Fuller, Mediation - Its Forms and Functions, 44 S. CAL. L. REv. 305, 310 (1971).

43. See Thomas Crum, The Magic of Confzict: Turning a Life of Work Into a WORK OF ART 174-75 (1987); $c$. William URY et AL., GetTING Disputes Resolved: Designing Systems to Cut the Costs of Conflict 170 (1988).

44. See Bush \& Folger, supra note 29 passim. The ability to empathize with one's counterpart can produce numerous benefits. In Gandhi's words: "Three fourths of the miseries and misunderstandings in the world will disappear if we step into the shoes of our adversaries and understand their standpoint." ESSENTIAL GANDHI 255 (Louis Fischer ed., 1962).

45. See James A. Wall, Jr. \& Ronda R. Callister, Ho'oponopono: Some Lessons from Hawaiian Mediation, 11 NEG. J. 45 (1995). 
their connectedness. ${ }^{47}$ They might learn to understand themselves better, to give up their anger or desire for revenge, ${ }^{48}$ to work for inner peace, ${ }^{49}$ or to otherwise improve themselves. ${ }^{50}$ They also might learn to live in accord with the teachings or values of a community to which they belong. 51

\section{Level IV: Community Interests}

"Level IV" mediations consider an even broader array of interests, including those of communities or entities that are not parties to

46. See Steven B. Goldberg et al., Dispute Resolution: Negotiation, Miedia. Tion, AND OTher Processes 137-39 (2d ed. 1992); Hank de Zutter, Proponents Say ADR Spells Relief, Ill. Legal Tmes, Jan. 1988, at 1; Comment, Healing Angry Wounds: The Roles of Apology and Mediation in Disputes Between Physicians and Patients, J. DisP. RESOL. 126-27 (1987).

47. See Zrena D. Zumeta, Spirituality and Mediation, 11 MÉdiation Q. 25, 25 (1993) (discussing the creation and nurture of connectedness in mediation). See generally Beyond Technique: The Soul of Family Mediation, 11 Míndatron Q. 1 (1993) (discussing the role of emotion and spirituality in family mediations).

48. See Kenneth Cloke, Revenge, Forgiveness, and the Magic of Mediation, $11 \mathrm{ME}$ DIATION Q. 67, 67 (1993) (describing methods to encourage parties to forgive).

49. See UMaBreIT, supra note 6, at 75-82. Shinzen Young, an American Buddhist priest and teacher of Vipassana or "insight" meditation, makes available a process he calls "meditative mediation" when members of his community are engaged in a dispute. The process involves alternating between mediation and insight meditation. During the meditation, the parties observe their own internal reactions, which promotes insight, the goal of this practice. The parties use conflict as an opportunity to enhance their own development. See Shinzen Young, Medrtative Mediation (Insight Recordings, Santa Monica, CA, transcript on file with author).

50. See Lois Gold, Influencing Unconscious Influences: The Healing Dimension of Mediation, 11 Mediation Q. 55, 58-60 (1993) (characterizing mediation as part of a general "healing" paradigm).

51. The Mennonite Conciliation Service, although it avoids "creedal" approaches, seeks to do "justice" in its mediations. "To us justice is doing what is necessary to establish right relationships. Right relationships are those that honor mutual human worth, that redress past wrong as far as injuries are able to be redressed, and in which steps have been taken so that neither fear nor resentment play dominant roles." John P. Lederach \& Ron Kraybill, The Paradox of Popular Justice: A Practitioner's View, in The PossibIITY of Popular Justice: A Case Study of Cosndunity MEdiation In the UNITED States 357, 361 (Sally E. Merry \& Neal Milner eds., 1993). In mediations provided by the Christian Conciliation Service,

The purpose ... . is to glorify God by helping people to resolve disputes in a conciliatory rather than an adversarial manner. In addition to facilitating the resolution of substantive issues, Christian conciliation seeks to reconcile those who have been alienated by conflict and to help them learn how to change their attitudes and behavior to avoid similar conflicts in the future.

Institute for Christian Conclliation, Christian Conciliation Handbook 19 (Revision $3.2,1994)$. For an analysis of various ways to look at the transformative potential of mediation, see Carrie Menkel-Meadow, The Many Ways of Mediation: The Transformation of Traditions, Ideologies, Paradigms, and Practices, 11 NEG. J. 217 (1995) (book review). 
the immediate dispute. For example, perhaps the ambiguity in legal principles relevant to the Computec case has caused problems for other companies; the participants might consider ways to clarify the law, such as working with their trade associations to promote legislation or to produce a model contract provision. In other kinds of disputes, parties might focus on improving, or "transforming," communities. ${ }^{52}$

Figure 1 illustrates and summarizes the type of problems that appear along the problem-definition continuum. Of course, mediations that employ broader problem-definitions can include resolution

FIGURE 1

\section{PROBLEM-DEFINITION CONTINUUM}

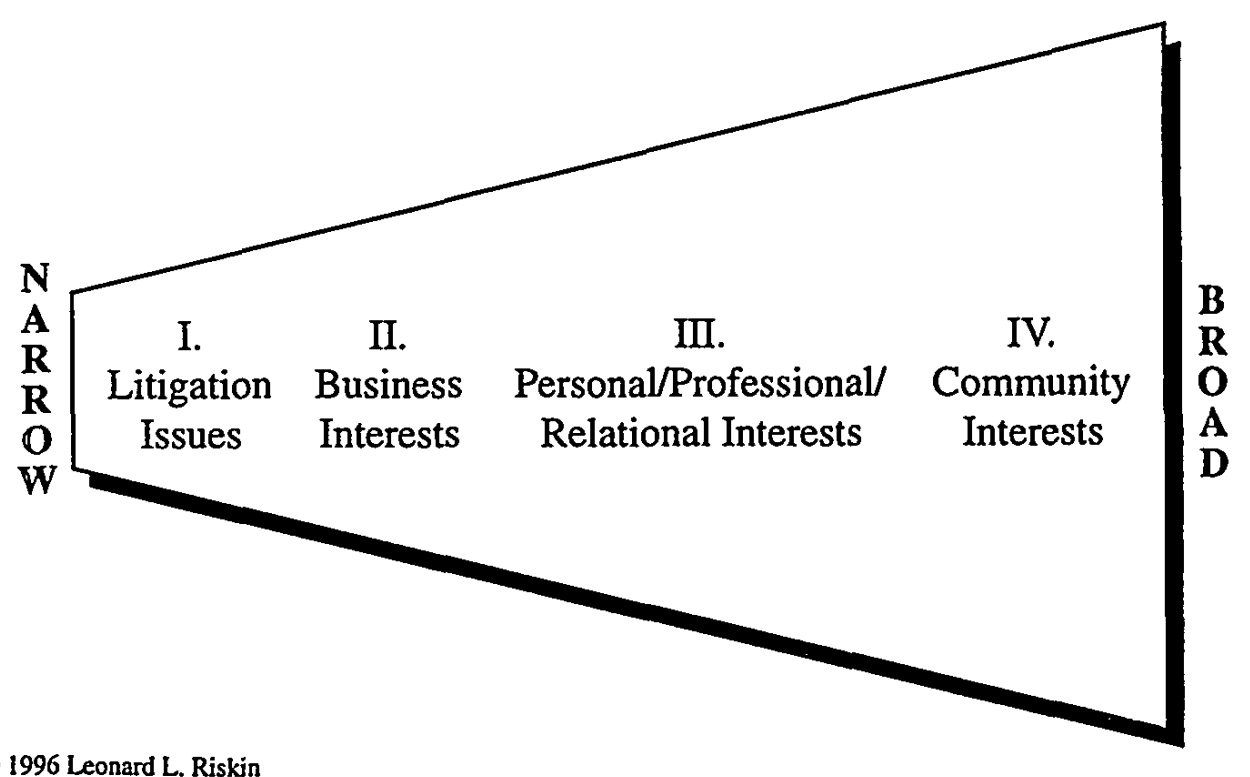

of narrower problems that appear to the left on the continuum. Thus, a mediation of the Computec case that addresses the underlying business interests also could resolve the distributive issue - how much of the $\$ 30,000$, if any, does Golden State pay to Computec? As the problem broadens, however, the distributive issue could become less important. Thus, if the two feuding executives learn to understand each other, instead of deciding how much Golden State will pay to Computec, they might arrive at an agreement that washes away that

52. See generally Lederach \& Kraybill, supra note 51 (exploring notions of popular justice and social transformation). 
distributive issue. For example, they might decide to serve the firms' underlying business interests by creating a joint venture to market computer services to financial institutions, with a $\$ 30,000$ seedmoney contribution from Golden State and an employee loaned by Computec. In other words, in moving from narrow to broad definitions of the subject matter of a mediation, one's view of the conflict can change from that of a problem to be eliminated to that of an opportunity for improvement.

Within a given mediation, a particular problem or issue can have either primary or secondary significance. In a very narrow mediation of Computec, for example, the primary focus is on how much of the $\$ 30,000$, if any, Golden State will pay. Yet, even in such a mediation, the participants might benefit in secondary, broader ways. They could, for example, feel vindicated, satisfied, or enlightened as to their own situation or that of their counterpart. This might permit greater empathy and the ability to rebuild their working relationship. And any of these developments could transform them, in ways large or small. In a narrow mediation, however, such outcomes claim only secondary importance, as occasional by-products of solving the central, distributive issue. The participants - including the mediator - may not think or care about such outcomes. ${ }^{53}$

\section{B. The Mediator's Role: Goals and Assumptions Along The Facilitative-Evaluative Continuum}

The second continuum describes the strategies and techniques that the mediator employs to achieve her goal of helping the parties address and resolve the problems at issue..$^{54}$ At one end of this continuum are strategies and techniques that evaluate issues important to the dispute or transaction. At the extreme of this evaluative end of

53. In a given mediation, of course, participants may have different goals or priorities and, therefore, may attach differing degrees of significance to resolving a particular issue.

54. Some commentators distinguish between "settlement" and "resolution," implying that settlement tends to result from a compromise on a narrov issue, whereas resolution seeks to deal with underlying problems. See J. Michael Keating, Jr. \& Margaret L. Shaw, "Compared to What?": Defining Terms in Court-Related ADR Programs, 6 NEG. J. 217 (1990) (suggesting that "settlement" typifies judicially-hosted settlement conferences but that "collaboration" or "resolution" should be the goal in mediation). 
the continuum fall behaviors intended to direct some or all of the outcomes of the mediation.55 At the other end of the continuum are beliefs and behaviors that facilitate the parties' negotiation. At the extreme of this facilitative end is conduct intended simply to allow the parties to communicate with and understand one another. ${ }^{56}$

The mediator who evaluates assumes that the participants want and need her to provide some guidance as to the appropriate grounds for settlement - based on law, industry practice or technology and that she is qualified to give such guidance by virtue of her training, experience, and objectivity.

The mediator who facilitates assumes that the parties are intelligent, able to work with their counterparts, and capable of understanding their situations better than the mediator and, perhaps, better than their lawyers. ${ }^{57}$ Accordingly, the parties can develop better solutions than any the mediator might create. Thus, the facilitative mediator assumes that his principal mission is to clarify and to enhance communication between the parties in order to help them decide what to do.

To explain the facilitative-evaluative continuum more fully, I must demonstrate how it relates to the problem-definition continuum. The relationship is clearest if we show the problem-definition continuum on a horizontal axis and the facilitative-evaluative continuum on a vertical axis, as depicted in Figure 2. The four quadrants each represent a general orientation toward mediation: evaluativenarrow, facilitative-narrow, evaluative-broad, and facilitative-broad.

\section{The Four Orientations: Strategies and Techniques}

Most mediators operate from a predominant, presumptive or default orientation ${ }^{58}$ (although, as explained later, many mediators

55. Professor Edward Dauer has called such a process "op-med." See EdWARD A.

Dauer, Manual of Dispute Resolution: ADR Law and Practice $\S \S 11-45$ (1994).

56. See Thomas Princen, Joseph Elder: Quiet Peacemaking in a Civil War, in

WhEN TALK Works, supra note 16, at 428.

57. See Riskin, supra note 10, at 1099-1108.

58. Kressel and his colleagues said the following about the common characteristics of the mediator styles that they identified:

First, a mediator's style tended to be consistent. A given mediator was likely to enact the same style from case to case, even in the face of considerably different issues or conflict dynamics. Second, mediator style appeared to operate below the level of conscious awareness; style was something mediators "did" without fully recognizing the underlying coherence or "logic" behind their style. Mediators were capable of articulating why they adopted the style they exhibited when their style was pointed out to them, but this took a conscious effort and the assistance of other team members. Finally, mediator 
FigURE 2

MEDIATOR ORIENTATIONS

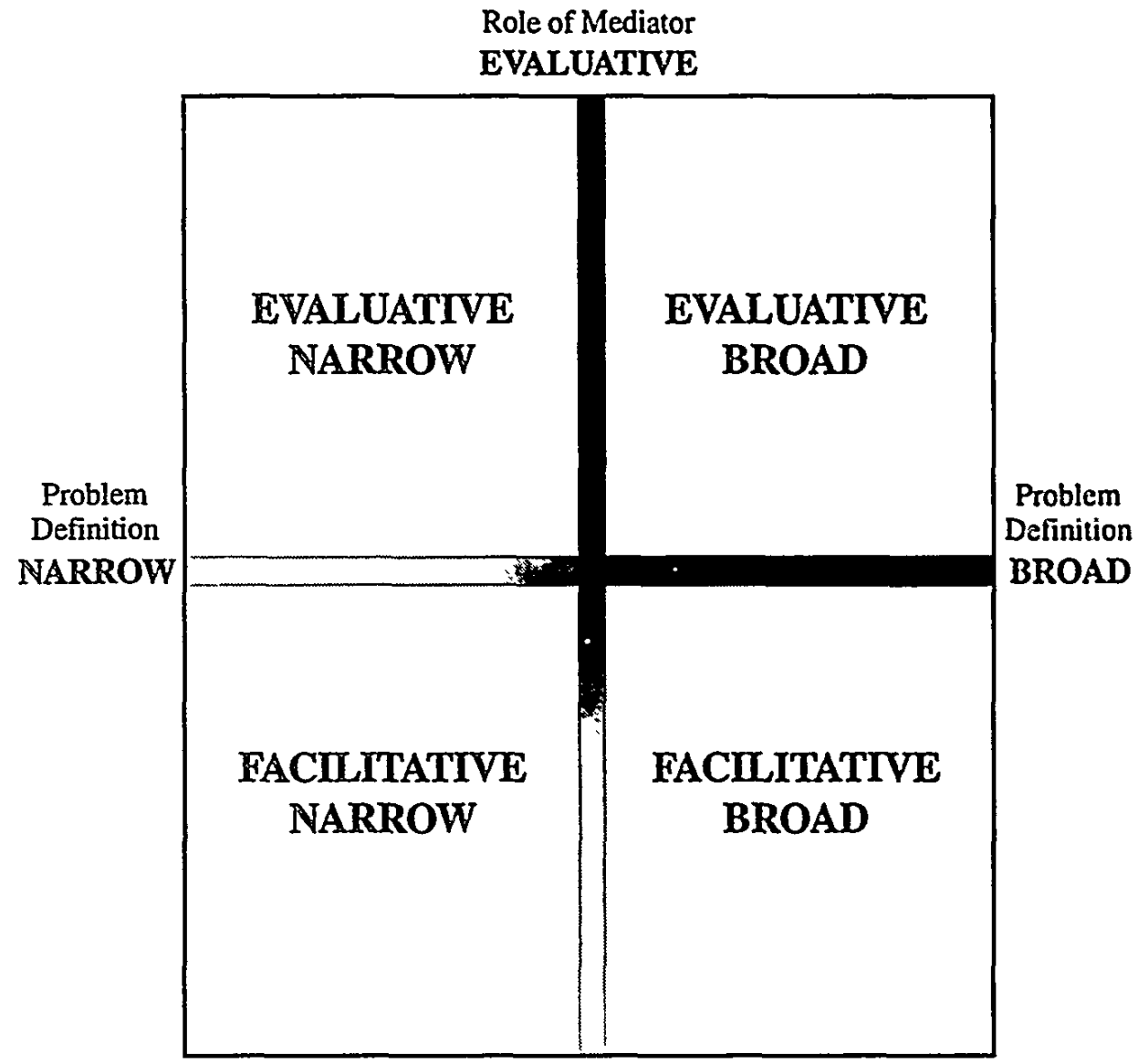

() 1996 Leonard L. Riskin

FACUITATIVE

move along continuums and among quadrants). ${ }^{59}$ For purposes of the following explication of mediator orientations, I will assume that

style could be modified, but this too took explicit direction or "training." Over the course of the project, and as a result of case conferencing, team members became more aware of their intrinsic stylistic inclinations and learned to shift to a more adaptive style where indicated.

Kressel et al., supra note 26, at 72-73.

Kressel and Pruitt write that there are two bases that mediators use to decide what kind of interventions to make: "[t]he mediator's active monitoring of the unfolding conflict; [and] the mediator's often unarticulated preference for a particular style of mediation." Kenneth Kressel \& Dean G. Pruitt, Conclusion: A Research Perspective on the Mediation of Social Conflict, in Kressel \& PruTt, supra note 28, at 394, 422. See also Silbey \& Merry, supra note 27, at 19. Although they highlight the tendency of mediators to respond to circumstances, Professors Silbey and Merry note that "mediation strategies tend to be more pronounced and stylized toward one or the other mode with increased experience." Id.

59. See discussion infra Part II.D. 
the mediator is acting from such a predominant orientation. For this reason, and for convenience, I will refer to the "evaluative-narrow mediator" rather than the more precise, but more awkward, "mediator operating with an evaluative-narrow approach."

A mediator employs strategies - plans - to conduct a mediation. And a mediator uses techniques - particular moves or behaviors - to effectuate those strategies. Here are selected strategies and techniques that typify each mediation orientation. ${ }^{60}$

\section{Evaluative-Narrow}

A principal strategy of the evaluative-narrow approach is to help the parties understand the strengths and weaknesses of their positions and the likely outcome of litigation or whatever other process they will use if they do not reach a resolution in mediation. But the evaluative-narrow mediator stresses her own education at least as much as that of the parties. ${ }^{61}$ Before the mediation starts, the evaluative-narrow mediator will study relevant documents, such as pleadings, depositions, reports, and mediation briefs. At the outset of the mediation, such a mediator typically will ask the parties to present their cases, which normally means arguing their positions, in a joint

60. At this point, I wish simply to describe - and to describe simply - the proposed system of categorization. For convenience, I sometimes will write as if the mediator alone defines the problem and selects the strategies and techniques she will employ. However, the question of how the mediator and the parties do, can, and should determine the scope and nature of a given mediation is extremely complex. Accordingly, I plan to avoid it in this Article and address it in a subsequent work.

My approach to describing the activities of mediators differs from that developed by Silbey and Merry. Their "ideal types" - the "bargaining style" and the "therapeutic stylen - provide examples, respectively, of tendencies toward narrow or broad problem-definition. See Silbey \& Merry, supra note 27, at 19. Silbey and Merry observed that mediators' behavior fell along a continuum, with these two styles representing the poles. They did not focus on the evaluative-facilitative dimension, however, probably because they seemed to believe that in both categories the mediator manipulated the parties into settlement. See id. at 14. Silbey and Merry did not intend their styles to be used to categorize mediators; in fact, they argue that all mediators that they observed used both styles. Rather, they characterize the mediation styles they constructed as model/ideal types, Weberian analytical constructs that do not exist in reality. In contrast, I believe that the orientations that I set out do accurately describe the practices of a substantial number of mediators - although some mediators draw from each quadrant. See infra Part II.D.

61. See Kenneth Feinberg, Mediation - A Preferred Method of Dispute Resolution, 16 PePp. L. REv. S5, S12-S20 (1989). 
session. Subsequently, most mediation activities take place in private caucuses in which the mediator will gather additional information and deploy evaluative techniques, ${ }^{62}$ such as the following, which are listed below from the least to the most evaluative.

a. Assess the strengths and weaknesses of each side's case. - In the Computec case, an evaluative mediator might tell Computec's representatives that, even if a court were to interpret the law as they hoped, the firm would have trouble meeting its burden of establishing the existence of an industry custom that purchasers of such services normally pay the related travel expenses of their suppliers. The mediator would explain her reasoning, invoking her experience and knowledge.

b. Predict outcomes of court or other processes. - In Computec, the mediator might predict for Golden State the likely rulings on issues of law and fact, the likely outcome at trial and appeal, and the associated costs.

c. Propose position-based compromise agreements. - A mediator can make such proposals with varying degrees of directiveness. Some mediators might suggest resolution points so gently that they are barely evaluative - for instance, throwing out a figure at which she thinks the parties might be willing to settle, without suggesting that this corresponds to what would happen in court or is otherwise an appropriate settlement point. ${ }^{63}$ A slightly more directive proposal might be to ask Computec, "Would you accept $\$ 12,000$ ?" or "What about $\$ 12,000$ ?" A still more directive proposal would be to suggest that the case might settle within a certain range, say $\$ 10,000$ $\$ 15,000$. An even more directive move would be to say, "I think $\$ 12,000$ would be a good offer." 64

62. See id. James C. Freund has developed his own twelve-step method for dealing with disputes over money. See James C. Freund, The Neutral Negotiator: Why and How Mediation Can Work to Resolve Dollar Disputes 17, 37-48 (1995).

63. See Alan Alhadeff, What is Mediation?, in The Alternative Dispute Resolu. tTon Practice Guide § 23:9 (Bette J. Roth et al., eds., 1993). This soft suggestion technique also could be employed by a facilitative-narrow mediator as the most evaluative technique in his repertoire.

64. Sometimes such proposals can be quite creative. See FreUnd, supra note 62, at 44-45. The timing of a mediator's proposal might affect its degree of directiveness. Some mediators, whose conduct I consider extremely evaluative, will make assessments and proposals immediately after learning the facts of the case. See Feinberg, supra note 61, at S17-S18. Others will use a less directive technique - vithholding such assessments until the parties request them, which often occurs after facilitative negotiations have failed. See DAUER, supra note 55, at $\S 11.14$. 
d. Urge or push the parties to settle or to accept a particular settlement proposal or range. - In the Computec case, the mediator might tell Computec that she thinks Computec "should" accept a settlement offer of $\$ 12,000$ because that would protect it against the risk and expense of litigation or because it is "right" or "fair" or "reasonable." 65 If the mediator has any sort of "clout," she may threaten to use it. Or she may engage in "head-banging." 66

\section{Facilitative-Narrow}

The facilitative-narrow mediator shares the evaluative-narrow mediator's general strategy - to educate the parties about the strengths and weaknesses of their claims and the likely consequences of failing to settle. But he employs different techniques to carry out this strategy. He does not use his own assessments, predictions, or proposals. ${ }^{67}$ Nor does he apply pressure. He is less likely than the evaluative-narrow mediator to request or to study relevant documents. Instead, believing that the burden of decision-making should rest with the parties, the facilitative-narrow mediator might engage in any of the following activities.

a. Ask questions. - The mediator may ask questions - generally in private caucuses - to help the participants understand both sides' legal positions and the consequences of non-settlement. The questions ordinarily would concern the very issues about which the evaluative-narrow mediator makes statements - the strengths and weaknesses of each side's case and the likely consequences of nonsettlement, as well as the costs of litigation (including expense, delay, and inconvenience). 68

65. For examples of such techniques, see Lavinia Hall, Eric Green: Finding Alter. natives to Litigation in Business Disputes, in WHEN TALK WoRKs, supra noto 16, at 279.

66. Kenneth Feinberg seems to use most of the evaluative techniques in a very structured manner; he increases pressure as the mediation moves on. See Feinberg, supra note 61, at S12-S20.

67. The facilitative mediator believes that it is inappropriate for the mediator to give his opinion, for several reasons. First, such opinions might impair the appearance of impartiality and thereby the mediator's ability to function. Second, if the parties know that the mediator is likely to make an assessment of the legal merits of their case, they are less likely to give the mediator a candid assessment of the strengths and weakness of their claims in a private caucus. See Alhadeff, supra note 63 , at \& 23:8. Third, the mediator might not know enough - about the details of the case or the relevant law, practices or technology - to give an informed opinion.

68. Here are examples of the types of questions the facilitative-narrow mediator might ask: 1 . What are the strengths and weaknesses of your case? Of the other side's case? 2. What are the best, worst, and most likely outcomes of litigation? How 
b. Help the parties develop their own narrow proposals. - In the Computec case, for instance, a facilitative-narrow mediator would help each party develop proposals as to how much of the $\$ 30,000$ Golden State would pay.

c. Help the parties exchange proposals. - The mediator might present party proposals in private caucuses or encourage parties to make such proposals in a joint session. In either event, he would encourage participants to provide a rationale for each proposal that might help the other side accept it.

d. Help the parties evaluate proposals. - To do this, the mediator might ask questions that would help the parties weigh the costs and benefits of each proposal against the likely consequences of nonsettlement.

The facilitative nature of this mediation approach might also produce a degree of education or transformation. ${ }^{69}$ The process itself, which encourages the parties to develop their own understandings and outcomes, might educate the parties, or "empower" them by helping them to develop a sense of their own ability to deal with the problems and choices in life. ${ }^{70}$ The parties also might acknowledge or empathize with each other's situation. ${ }^{71}$ However, in a narrowlyfocused mediation, even a facilitative one, the subject matter normally produces fewer opportunities for such developments than does a facilitative-broad mediation. ${ }^{\mathbf{2}}$

\section{Evaluative-Broad}

It is more difficult to describe the strategies and techniques of the evaluative-broad mediator. Mediations conducted with such an orientation vary tremendously in scope, often including many narrow, distributive issues, as the previous discussion of the problemdefinition continuum illustrates. ${ }^{73}$ In addition, evaluative-broad

did you make these assessments? Have you thought about [other issues]? 3. How long will it take to get to trial? How long will the trial last? 4. What will be the associated costs - in money, emotions, or reputation? Note that a mediator also can use a question to make an evaluative statement. See infra note 97; Hall, supra note 65 , at 297.

69. See supra notes $42-52$ and accompanying text.

70. See BUSH \& FoLGER, supra note 29 , at $85-89$.

71. See id. at 89-94. For a more comprehensive vision of transformation, see Menkel-Meadow, supra note 51.

72. See infra notes 83-84.

73. See discussion supra Part II.A. 
mediators can be more-or-less evaluative, with the evaluative moves touching all or only some of the issues.

The evaluative-broad mediator's principal strategy is to learn about the circumstances and underlying interests of the parties and other affected individuals or groups, and then to use that knowledge to direct the parties toward an outcome that responds to such interests. ${ }^{74}$ To carry out this strategy, the evaluative-broad mediator will employ various techniques, including the following (listed from least to most evaluative).

a. Educate herself about underlying interests. - The evaluative-broad mediator seeks to understand the underlying legal and other distributive issues by studying pleadings, depositions, and other documents, as well as by allowing the parties (usually through their lawyers) to argue their cases during the mediation. Unlike the narrow mediator, however, the broad mediator emphasizes the parties' underlying interests rather than their positions, and seeks to uncover needs that typically are not revealed in documents. Pleadings in the Computec case, for instance, would not indicate that one of the causes of the dispute was Golden State's interest in protecting the sanctity of its internal policy against reimbursing convention travel expenses of its own employees, let alone that the policy was born when the CEO observed staff members, at a convention in Bermuda, frolicking instead of attending seminars.

For this sort of information, as well as other interests, the mediator must dig. To learn about the parties' underlying interests, the evaluative-broad mediator would be more likely than the narrow mediator to encourage or require the real parties (whether actual disputants or knowledgeable representatives of corporations or other organizations who possess settlement authority) to attend and participate in the mediation. For instance, the mediator might invite such individuals to make remarks after the lawyers present their opening statements, and she might interview such individuals extensively in private caucuses. She might explain that the goal of mediation can include addressing underlying interests, ask direct questions about interests, and seek such information indirectly by questioning the parties as to their plans, situations, and the like. Often, evaluative-broad mediators will speculate aloud about the parties' interests

74. For an excellent example of an evaluative-broad orientation, see Deborah $\mathrm{M}$. Kolb, William Hobgood: Conditioning Parties in Labor Grievances, in WHEN TALK Works, supra note 16, at 149; see also KoLB, supra note 28, at 72-112 (discussing the practices of state labor mediators, whom the author calls "deal makers"). 
(generally in private caucuses) and seek confirmation of their statements.

Evaluative-broad mediators expect to construct proposed agreements. For that reason, they generally emphasize their own education over that of the parties. Accordingly, they typically will restrict or control direct communication between the parties; thus, for example, the evaluative-broad mediator would spend more time in private caucuses than in joint sessions.

b. Predict impact (on interests) of not settling. - After determining the parties' underlying interests and setting the scope of the problems to be addressed in the mediation, some evaluative-broad mediators would predict how failure to settle would impact important interests.75 In the Computec case, an evaluative-broad mediator might tell Golden State that unless it reaches an agreement that allows Computec executives to feel appreciated and effective, relations will sour and Computec might become less diligent, thereby impairing Golden State's ability to compete and to serve its customers.

An evaluative-broad mediator also might try to persuade the participants that her assessments are correct by providing objective criteria or additional data.

c. Develop and offer broad (interest-based) proposals. - An evaluative-broad mediator's goal is to develop a proposal that satisfies as many of the parties' interests, both narrow and broad, as feasible. Proposals in the Computec case, for example, might range from a payment scheme for Golden State (based on an allocation of costs), to a system for the submission and approval of travel and education expenses in future years, to the formation of a new joint venture.

d. Urge parties to accept the mediator's or another proposal. The evaluative-broad mediator (like the evaluative-narrow mediator) might present her proposal with varying degrees of force or intended impact. If the mediator has clout (the ability to bring pressure to bear on one or more of the parties), she might warn them or threaten to use it. ${ }^{76}$

75. Like the evaluative-narrow mediator, an evaluative-broad mediator in the Computec case might render her opinion as to distributive (adversarial) issues by assessing the strengths and weaknesses of the parties' legal cases, predicting the outcome at trial, or recommending how much, if anything, Golden State should pay. But the evaluative-broad mediator generally focuses on the parties' underlying interests.

76. Special masters who employ mediation strategies and techniques often have the kind of power that makes it possible to put pressure on parties. See Vincent M. 
If the mediator has concluded that the goal of the mediation should include changing the people involved, she might take measures to effectuate that goal, such as appealing to shared values, ${ }^{77}$ lecturing, or applying pressure. ${ }^{78}$

\section{Facilitative-Broad}

The facilitative-broad mediator's principal strategy is to help the participants define the subject matter of the mediation in terms of underlying interests and to help them develop and choose their own solutions that respond to such interests. In addition, many facilitative-broad mediators will help participants find opportunities to educate or change themselves, their institutions, or their communities. ${ }^{79}$ To carry out such strategies, the facilitative-broad mediator may use techniques such as the following.

a. Help parties understand underlying interests. - To accomplish this task, the facilitative-broad mediator will engage in many of the same activities as the evaluative-broad mediator, such as encouraging attendance and participation by the real parties, not just their lawyers, ${ }^{80}$ and explaining the importance of interests. Because he expects the parties to generate their own proposals, the facilitativebroad mediator emphasizes the need for the parties to educate themselves and each other more than the mediator. Thus, in contrast to

Nathan, The Use of Special Masters in Institutinal Reform Litigation, 10 U. Tol. L. REv. 419 (1979). In addition, managers or others with authority over disputants often use their authority to coerce settlements. For example, when Linda Colburn managed a public housing project in Hawaii, she often engaged in a form of mediation she calls "peacemaking"; in order to defuse violent situations, she frequently employed threats. See Neal Milner, Linda Colburn: On-the-Spot Mediation in a Public Housing Project, in WhEN TALK WoRks, supra note 16, at 417.

President Jimmy Carter's mediations in the Israel-PLO dispute and the EthiopiaEritrea dispute demonstrate broad and very evaluative mediation. He pushed the parties hard, making moral arguments as well as suggesting ways in which the United States could help the parties if they reached agreement. See Eileen F. Babbitt, Jimmy Carter: The Power of Moral Suasion in International Mediation, in WHEN TALK WoRKS, supra note 16, at 377-78.

77. See supra note 50. Neutrals in the Christian Conciliation Service are "as concerned about reconciling the parties as they are about helping them settle their substantive differences." Christian Conciliation HandBooK, supra note 51, at 7. In the conciliation sessions, the neutrals "teach relevant biblical principles." Id. at 27. They also may issue advisory opinions. See id. at 28.

78. See, e.g., James A. Wall, Jr. \& Michael Blum, Community Mediation in the People's Republic of China, 35 J. Conflict Resol. 3, 9, 13 (1991).

79. See supra notes $41-51$ and accompanying text.

80. See Riskin, supra note 10, at 1097-1108. 
the evaluative mediator, the facilitative-broad mediator will be inclined to use joint sessions more than private caucuses. ${ }^{81}$

The facilitative-broad mediator also will help the parties define the scope of the problem to be addressed in the mediation, often encouraging them to explore underlying interests to the extent that they wish to do so. This behavior stands in sharp contrast to that of narrow mediators (even most facilitative-narrow mediators), who tend to accept the obvious problem presented, and that of evaluativebroad mediators, who often define the scope of the problem to be addressed themselves. ${ }^{82}$

Many facilitative-broad mediators especially value mediation's potential for helping parties grow through an understanding of one another and of themselves. These mediators tend to offer the participants opportunities for positive change. One way to look at this is through Bush and Folger's concept of "transformation." view, by encouraging the parties to develop their own understandings, options, and proposals, the facilitative-broad mediator "empowers" them; by helping the parties to understand one another's situation, the facilitative-broad mediator provides them opportunities to give "recognition" to one another. ${ }^{84}$

81. See Gary J. Friedman, A Guide to Divorce Miediation 36-37 (1993).

82. The facilitative-broad mediator does not ignore the litigation and other narrow issues; in fact, he might address these issues in the same fashion as the facilitative-narrow mediator. In other words, he would attempt to help the parties understand the strengths and weaknesses of each side's claims, but not by providing assessments, predictions, or proposals. Instead, he typically will allow the parties to present and discuss their legal arguments. In addition, in private caucuses, he might ask questions about litigation and other distributive issues, such as those listed for the facilitative-narrow mediator. See discussion supra Part II.C.2.

In a broad mediation, however, legal argument generally occupies a lesser position than it does in a narrow one. And because he emphasizes the participants' role in defining the problems and in developing and evaluating proposals, the facilitativebroad mediator does not need to fully understand the legal posture or other details of the case. Accordingly, he is less likely to request or study litigation documents, technical reports, or mediation briefs.

83. See BUSH \& FOLGER, supra note 29, at 84. For a description of a facilitative mediator who emphasizes empowerment, see Sally E. Merry, Albie M. Davis: Community Mediation as Community Organizing, in WhEN TALK WORks, supra note 16, at 245 .

84. In Bush and Folger's view, "parties achieve recognition in mediation when they voluntarily choose to become more open, attentive, sympathetic and responsive to the situation of the other party, thereby expanding their perception to include an appreciation for another's situation." BUSH \& FOLGER, supra note 29, at 89 . In a mediation of the Computec case, for instance, executives from each firm who were embroiled in controversy with counterparts in the other firm might learn to understand one another's situations better; such understanding could be seen as valuable in its own right - whether or not it contributed to the resolution of the narrow issues 
b. Help parties develop and propose broad, interest-based options for settlement. - The facilitative-broad mediator would keep the parties focused on the relevant interests and ask them to generate options that might respond to these interests. ${ }^{85}$ In the Computec case, the options may include various systems through which the already-incurred expenses could be allocated to the Golden State contract, methods for handling the same issue in the future (informally or by contract amendment), and opportunities to collaborate on other projects (an example of positive change). Next, he would encourage the parties to use these options - perhaps combining or modifying them - to develop and present their own interest-based proposals.

c. Help parties evaluate proposals. - The facilitative-broad mediator uses questions principally to help the parties evaluate the impact on various interests of proposals and of non-settlement. In Computec, for instance, a facilitative-broad mediator might ask the Computec representative how a specific settlement would affect the parties' working relationship and how it would alter Computec's ability to deliver appropriate services. ${ }^{86}$

Figure 3 highlights the principal techniques associated with each orientation, arranged vertically with the most evaluative at the top and the most facilitative at the bottom. The horizontal axis shows the scope of the problems to be addressed, from the narrowest on the left to the broadest on the right.

in dispute. See supra notes $41-50$ and accompanying text. For a more comprehensive view of transformation, see Menkel-Meadow, supra note 51.

85. In developing a comprehensive agreement in Computec, the parties might seek to include terms that respond to their mutual interests in reestablishing and maintaining a good working relationship; in feeling fairly treated; in enhancing and maintaining Computec's ability to provide computerized financial services to Golden State; in ending this particular dispute and minimizing the costs of resolution; in continuing to make profits; or in maintaining good reputations.

86. Obviously not all facilitative mediators employ all of these techniques. In addition, some mediators are so facilitative that the broad-narrow continuum does not apply. These mediators simply help the parties define the problem and then facilitato communication. Quaker peacemaking, a form of "second-track diplomacy," offers excellent examples of this approach. See, e.g., Princen, supra note 56 passim. 


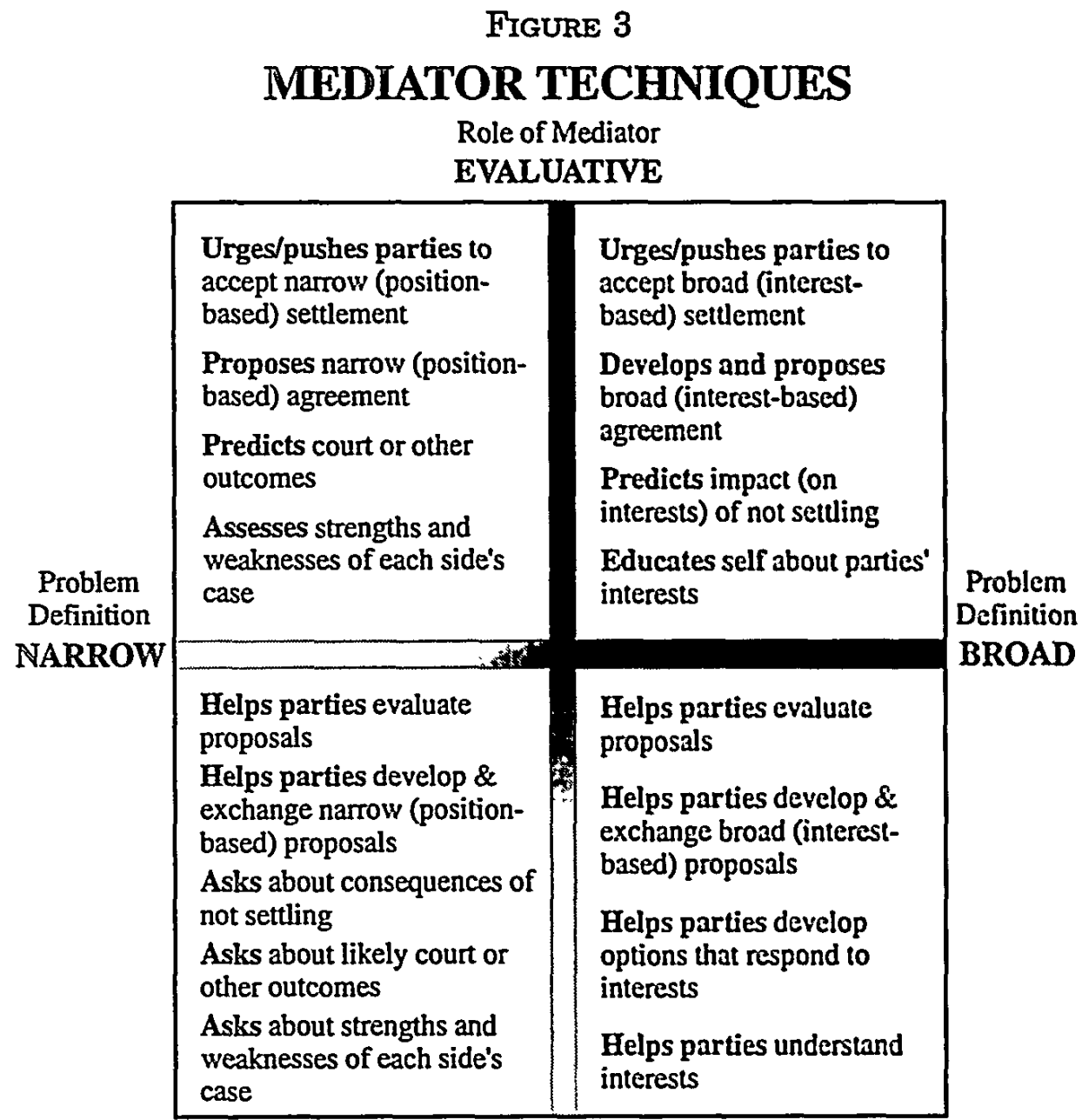

(1) 1996 Leonard L. Riskin

\section{FACILITATIVE}

D. Movement Along the Continuums and Among the Quadrants: Limitations on the Descriptive Capabilities of the Grid

Like a map, the grid has a static quality that limits its utility in depicting the conduct of some mediators.

It is true that most mediators - whether they know it or not generally conduct mediations with a presumptive or predominant orientation. ${ }^{87}$ Usually, this orientation is grounded in the mediator's personality, education, training, and experience. For example, most retired judges tend toward an extremely evaluative-narrow orientation, depicted in the far northwest corner of the grid. Many divorce mediators with backgrounds or strong interests in psychology or

87. See supra note 58 and accompanying text. 
counseling - and who serve affluent or well-educated couples - lean toward a facilitative-broad approach. ${ }^{88}$ Sometimes, the expectations of a given program dictate an orientation; for example, narrow mediation tends to dominate many public programs with heavy caseloads. ${ }^{89}$

Yet many mediators employ strategies and techniques that make it difficult to fit their practices neatly into a particular quadrant. First, some mediators deliberately try to avoid attachment to a particular orientation. Instead, they emphasize flexibility and attempt to develop their orientation in a given case based on the participants' needs ${ }^{90}$ or other circumstances in the mediation. ${ }^{91}$

Second, for a variety of reasons, some mediators who have a predominant orientation do not always behave consistently with it.92 They occasionally deviate from their presumptive orientation in response to circumstances arising in the course of a mediation. In some cases, this substantially changes the scope of the mediation. A mediator with a facilitative-broad approach handling a personal injury claim, for instance, normally would give parties the opportunity to explore underlying interests. But if the parties showed no inclination

88. See, e.g., Friedman, supra note 81 , at 37.

89. As Deborah Kolb has suggested, mediation tends to take on the characteristics of the process it replaces. See Deborah M. Kolb, How Existing Procedures Shape Alternatives: The Case of Grievance Mediation, 1989 J. Disp. Resol. 59. Thus, courtconnected mediation programs tend to be narrow. See Alfini, supra note 27, at 66.

90. See Letter from Donald B. Reder, President, Dispute Resolution, Inc., Hartford, Connecticut to Leonard L. Riskin (Sep. 28, 1994) (on file with author) ("In short, I think a good mediator needs to be prepared to be all the things you describe and must know when and to whom to be which. This is the art of mediation."). Advising lawyers, Eric Galton writes:

The best of all worlds is to identify a mediator who is versed in all styles and who has the capacity to be flexible. I have begun several mediations on a case evaluation track and during the process discovered, based on the personalities of the participants, that a community, more directly party-interactive, approach would be more effective. From the mediator's perspective, any variation of the process that is more likely to attain resolution should be the "right" process for that dispute.

GALTON, supra note 27 , at 4.

91. Linda Colburn, for example, uses radically different approaches in different settings. In her "generic" mediations in the Honolulu Neighborhood Justice Center, she uses a facilitative-broad approach. But when she engages in "peacemaking," resolving disputes in a public housing project in which she has management authority, she sometimes uses threats (along with humor and other techniques designed to disorient the parties), largely in order to avoid violence. See Milner, supra note 76, at 395.

92. Some mediators lack a clear grasp of the essence of their own expressed orientation. 
in that direction, the mediator probably would move quickly to focus on narrower issues.93

In other cases, a mediator might seek to foster her dominant approach using a technique normally associated with another quadrant. Thus, some mediators with predominantly facilitative-broad orientations might provide evaluations in order to achieve specific objectives consistent with their overall approach. Gary Friedman, an extremely facilitative-broad mediator, is a good example. When mediating divorces, Friedman typically follows the practice - standard among divorce mediators - of meeting with the parties alone, without their lawyers. In these sessions he routinely predicts judicial outcomes. He also emphasizes the principles underlying the relevant rules of law, and then encourages the parties to develop a resolution that makes sense for them and that meets their own notions of fairness. In essence, he evaluates in order to free the parties from the potentially narrowing effects of the law. 94

Frances Butler, who mediates child-custody disputes for a $\mathrm{New}$ Jersey court, provides another example. She uses a mixture of facilitative and evaluative techniques in the service of a broad, facilitative agenda: she asks questions (a facilitative technique) to help her understand the situation, then makes proposals (an evaluative technique), and then solicits the parties' input (a facilitative technique) in order to modify the proposals. ${ }^{95}$

A narrow mediator who runs into an impasse might offer the parties a chance to broaden the problem by exploring underlying interests. This might lead to an interest-based agreement that would enable the parties to compromise on the distributive issue as part of a

93. A mediator with a facilitative-broad orientation who faces a case that the parties seem to view narrowly may try to give the parties the opportunity to broaden the problem definition so as to explore underlying business or personal interests. Such a mediator faces a strategic choice. The mediator may wish to allow the parties first to focus narrowly on, say, the litigation issues, on the theory that they may need to go through stages of positioning and argumentation before they can settle down to look at underlying interests. See Gerald R. Williams, Legal Negotiation and SETtLe MENT 72-80 (1983). On the other hand, the mediator may try to open the parties to underlying interests as a preliminary matter on the theory that, in this way, the parties might avoid adversarial squabbling.

94. See Friedman, supra note 81 , at 49-50.

95. See Kenneth Kressel, Frances Butler: Questions That Lead to Answers in Child Custody Mediation, in When Talk Works, supra note 16, at 17.

Susan Silbey and Sally Merry, who distinguish between "bargaining" and "therapeutic" styles of mediation, conclude that an implicit negotiation determines the extent to which one or the other model prevails. See Silbey \& Merry, supra note 27, at 19. They also note, however, that "mediation of family disputes typically begins with a therapeutic style and closes with a bargaining style." Id. at 28. 
more comprehensive settlement. ${ }^{96}$ Similarly, a broad mediator might encourage the parties to narrow their focus if the broad approach seems unlikely to produce a satisfactory outcome. ${ }^{97}$

For these reasons it is often difficult to categorize the orientation, strategies, or techniques of a given mediator in a particular case. ${ }^{98}$

\section{EfFectiveness of the Grid, Especially iN Selecting MEDiators}

Despite these limitations, the grid can enable people to communicate with some clarity about what can, does, and should happen in a mediation. Accordingly, it can help sharpen discussions and facilitate decisions about the education, training, evaluation, and regulation of mediators. It can help disputants decide whether to mediate or to employ another process. Each of these tasks is quite complex, however. For that reason, I limit my comments in this section to a

96. See Galton, supra note 27 , at 4.

97. Speaking generally, broad mediators, especially facilitative ones, are more willing and able to narrow the focus of a dispute than are narrow mediators willing and able to broaden it. Professor Robert Ackerman suggests that "[t]his is probably because it is easier to narrow one's focus after exploring alternatives than to suddenly broaden one's focus after having set out down a narrow path." Letter from Professor Robert A. Ackerman, The Dickinson School of Law, to Leonard L. Riskin (Oct. 5, 1994) (on file with author). Again speaking generally, evaluative mediators are more willing to facilitate than facilitative mediators are to evaluate. However, many evaluative mediators lack facilitation skills, and vice versa.

98. In addition, as Professor David Matz has written in the context of evaluating mediators:

Any given move made by a mediator can have many meanings. A question asked by the mediator can elicit particular information. The same question can also serve to emphasize certain facts in the case and thus help persuade the party to consider the dispute from a different point of view. And the same question can help reframe the party's awareness of the alternatives available. Did the mediator intend all of these? Any of these? Or was he/she just filling time trying to think of something useful to do?

David E. Matz, Some Advice for Mediator Evaluators, 9 NEg. J. 327, 328 (1993). A case in point is Patrick Phear, a Boston divorce mediator who has an extremely broad and extremely facilitative orientation, marked by a "no advice" policy. He departs from that policy, however, and will give advice after the parties have reached "intimacy." See Sarat, supra note 16, at 191. Sarat explains:

When intimacy is achieved, the parties trust each other, the mediation process, and the mediator so much that the sentence "Why won't you take $\$ 50,000$ to settle this?" is heard as just one more question, not as what the mediator thinks you should settle on. Phear claims he can tell when people reach the stage of intimacy because they are "open, receptive ... They start talking about other people's interests as well as their own, and about process needs as well as outcome needs." They have, in essence, internalized the ideology of mediation.

Id. at 206 
brief consideration of how the grid can enhance decision-making about the selection of mediators.99

Some mediation programs give parties little or no choice in selecting mediators. Others allow parties to select from a pre-approved roster. In some situations, parties may chose virtually any mediator, constrained only by time and money. The grid may prove useful in each of these contexts, even though it does not describe all of the qualities that are important in a mediator. ${ }^{100}$

99. The process of thoughtfully matching a mediator to a particular dispute can be quite complex, particularly in situations where the decision requires negotiations among parties, lawyers, program administrators, and mediators. For that reason, I plan to examine that subject in greater detail in a subsequent article.

The identity of the neutral party affects settlement rates and levels of satisfaction among both participants and lawyers. See Karl D. Schultz, Florida's AltERnatrve Dispute Resolution Demonstration Project: An Empirical Assessarent (Fla. Dispute Resolution Center, undated); Rosenberg \& Folberg, supra note 14, at 1496.

100. Arthur Chaykin of the Sprint Corporation has suggested that a mediator should have "the key personal qualities of honesty, integrity, courage, and persistence." Arthur A. Chaykin, Selecting the Right Mediator. DISP. Resol. J., Sept. 1994, at 58,65. Jerry Conover, of the Faegre Group in Denver and Minneapolis, has tried to capture the qualities of a good mediator under the terms "creativity, diligence, and leadership." Jerry Conover, What Makes an Effective Mediator?, Alternatives to THE HIGH COST OF LITIGATION, Aug. 1994, at 101. Hans Stucki, senior litigation counsel at Motorola, Inc., maintains that often he would choose a mediator with "credibility," which sometimes means public recognition (what he calls "flash"). over one with well-developed mediation skills. See Hans U. Stucki, Mediator's Credibility is Key' Predictor of Success in ADR, Alternatives to the High Cost of Litigation, Jan. 1995, at 3.

The CPR Institute for Dispute Resolution, a non-profit organization sponsored by lawyers for the largest U.S. corporations, maintains panels of neutrals who must have the following attributes:

1. Outstanding career record

2. Unquestionable integrity

3. Highest respect of the bar and community

4. Judicious temperament

5. Talent for negotiation and conciliation

6. Creativity and flexibility

7. Experience and interest in ADR.

See CPR Institute for Dispute Resolution, CPR Panels of Distinguished NeuTRALS (undated).

Recently-published guidelines for selecting and training mediators list sixteen important "knowledges, skills, abilities and other attributes": reasoning, analyzing, problem-solving, reading comprehension, writing, oral communication, non-verbal communication, interviewing, emotional stability/maturity, sensitivity, integrity, recognizing values, impartiality, organizing, following procedure, and commitment. See Test Design Prosect, supra note 7, at 19.

In some situations, a mediator may need a familiarity with a particular culture or group or industry in order to be effective; in other situations, an absence of such connection may be essential in order to demonstrate impartiality. See Lederach \& Kraybill, supra note 51, at 363-69. Sometimes a mediator vill need to have command of certain knowledge or technology. See infra notes 121-123 and accompanying text. 
The grid can help in selecting a mediator because it includes virtually all activities that are widely considered mediation. Some will object to this breadth and may wish to customize the grid. For example, some will argue that an extremely evaluative-narrow approach (the northwest corner of the grid) really describes a different process, one that is closer to "neutral evaluation," "settlement," or "non-binding arbitration." People who hold this view might wish to cut off the northwest corner of the grid. Others would wish to eliminate the southeast corner, arguing that processes falling within this zone really should be called by another name, such as facilitation. ${ }^{101}$ [See Figure 4 in Appendix.] And some would remove or rename the two upper quadrants on the theory that evaluative mediation is a contradiction in terms. ${ }^{102}$

Still other commentators will argue that both continuums are too long to describe mainstream approaches to mediation. They might propose to mark these continuums in order either to allow a smaller zone to describe the world of mediation or to distinguish between core and peripheral approaches to the practice. ${ }^{103}$ [See Figure 5 in Appendix.]

The grid can help us envision an ideal mediator for any individual case. She would be sufficiently flexible to employ the most appropriate orientation, strategies, and techniques as the participants'

Lois Gold writes that mediator "presence" can enhance effectiveness. It consists of "(1) being centered; (2) being connected to one's governing values and beliefs and highest purpose; (3) making contact with the humanity of the clients; and (4) being congruent." Gold, supra note 50, at 56.

101. In some labor mediation programs, for instance, "transformative" approaches may be seen as "virtually a separate professional practice, under the heading of labormanagement cooperation." Test Design Project, supra note 7, at 21.

Some colleagues have contended that mediation approaches in the extreme southeast corner should be called psychotherapy. But such an argument reveals a limited understanding of the varieties of psychotherapy practiced today. In fact, we could use the grid to depict approaches to psychotherapy or to professional-client relations in other professions, such as law, architecture, urban planning, and medicine. See Donald A. Shon, The Reflective Practitioner passim (1983).

102. See Kimberely K. Kovach \& Lela P. Love, "Evaluative" Mediation Is an Oxymoron, Alternatives to the High Cost of Litigation, Mar. 1996, at 31; see Bush \& FOLGER, supra note 29 passim.

103. I have received many other suggestions about how to improve this grid, primarily from participants in various conferences at which I presented it. People suggested that the grid would be more effective if it were circular, instead of square; lacked outer boundaries; employed dotted, translucent, or wavy lines; included a shaded background; and were presented in colors or in three dimensions. Each of these suggestions has merit. My own limitations, as well as a desire for simplicity, kept me from adopting any of them. 
needs present themselves. ${ }^{104}$ This would require the ability (1) to both evaluate and facilitate, and (2) to see things both narrowly and broadly. She would have subject-matter expertise and she would be impartial. Plainly, some such mediators are available. Individual mediation programs might employ the grid to make choices about selection, training, ${ }^{105}$ assignment, evaluation, or retention so as to foster flexibility in individual mediators. Flexibility is a difficult trait to foster, however. Practical reasons, such as time, cost, and knowledge, may make it difficult to identify, develop, or assign such ideal mediators in a given situation.

Assuming a shortage of such "all-purpose" mediators, mediation programs may wish to select mediators with diverse backgrounds so as to make available mediators with varying approaches to match with appropriate cases. The grid can facilitate this process. Because parties or programs often will not be able to produce a flexible mediator who has the other required qualities, ${ }^{106}$ it is important that they understand that each approach to mediation carries potential advantages and disadvantages, which I will set forth below. In addition, I will demonstrate how the grid can help parties or program administrators evaluate the relative importance of two other qualities in a mediator: subject-matter expertise and impartiality.

\section{A. The Potential Advantages and Disadvantages of the Various Approaches to Mediation}

Assume that you represent Computec in its dispute with Golden State and that you and your counterpart have agreed (with the consent of both clients) to try mediation. Before considering the characteristics that you would like to see in the mediator and in the mediation process, you need to ask yourself two questions: first, what has blocked the success of the negotiations to date; ${ }^{107}$ and, second, what do you hope to achieve through mediation? ${ }^{108}$ You must find a

104. See GaLton, supra note 27 , at 4.

105. Most mediation training in the United States is grounded principally on a facilitative-broad approach. Nonetheless, vast numbers of graduates of these programs tend toward evaluative-narrow approaches.

106. See supra note 100 .

107. For a discussion of barriers to negotiation, see Robert H. Mnookin, Why Negotiations Fail: An Exploration of Barriers to the Resolution of Conflict, 8 Oно ST. J. DisP. RESOL. 235 (1993).

108. Arthur Chaykin has proposed four factors to consider in choosing a mediator:

(1) the type of negotiation the parties have been conducting; (2) the nature of the problem that is interfering with the negotiation process; (3) the type of negotiation the parties want to conduct to resolve the dispute; and (4) 
mediator whose approach to mediation and other characteristics are most likely to remove obstacles to settlement or otherwise help you accomplish your goals.

To know which orientation on the grid is most appropriate, one must comprehend a great deal about the origins and nature of the dispute, the relationships among the concerned individuals and organizations (both behind and across party lines), and their fears, levels of competence, and goals. Before mediation begins, however, parties and lawyers often will not fully understand these matters; individuals are likely to have different perceptions of what is needed, possible, or desirable in the mediation. These divergent perceptions may interfere with the parties' ability to select the most appropriate form of mediation. Accordingly, and because mediators may fail to test their assumptions about the parties' needs and may thus exercise what Felstiner and Sarat have called "power by indirection," 109 it is important for parties to understand the potential advantages and disadvantages of various points on the two continuums.

\section{The Problem-Definition Continuum}

a. Narrow Problem-Definition. - A narrow problem-definition can increase the chances of resolution and reduce the time needed for the mediation. The focus on a small number of issues limits the range of relevant information, thus keeping the proceeding relatively simple. In addition, a narrow focus can avoid a danger inherent in broader approaches - that personal relations or other "extraneous issues" might exacerbate the conflict and make it more difficult to settle.

whether special expertise or unusual credentials are required of the third party.

Chaykin, supra note 100 , at 59.

Frank Sander and Stephen Goldberg have developed an extensive method for helping parties choose a dispute resolution procedure based on these questions: "First, what are the client's goals, and what dispute resolution procedure is most likely to achieve those goals? Second, if the client is amenable to settlement, what are the impediments to settlement, and what ADR procedure is most likely to overcome those impediments?" Frank E.A. Sander \& Stephen B. Goldberg, Fitting the Forum to the Fuss: A User-Friendly Guide to Selecting an ADR Procedure, 10 NEG. J. 49, 50 (1994). They discuss which methods are likely to overcome the following impediments: poor communication, need to express emotions, different view of facts, different view of law, important principle, constituent pressure, linkage, multiple parties, different lawyer-client interests, and the jackpot syndrome. See id. at 55. A similar analysis could help determine the most appropriate approach to mediation.

109. See William L.F. Felstiner \& Austin Sarat, Enactments of Power: Negotiating Reality and Responsibility in Lawyer-Client Interactions, 77 CORNELL L. REv. 1447, 1476 (1992). 
On the other hand, in some cases the narrow approach can increase the chance of impasse because it allows little room for creative option-generation or other means of addressing underlying interests, which, if unsatisfied, could block agreement. Also, a narrow approach to mediation might preclude the parties from addressing other long-term mutual interests that could lead to long-lasting, mutually-beneficial arrangements. ${ }^{110}$

b. Broad Problem-Definition. - A broad problem-definition can produce an agreement that accommodates the parties' underlying interests, as well as the interests of other affected individuals or groups. Such an agreement is substantively superior. Broadening the problem-definition also can both increase the likelihood of settlement and reduce the time necessary for the mediation; when such a process addresses the parties' needs and allows room for creativity, it reduces the likelihood of impasse. In addition, it can provide opportunities for personal change. ${ }^{111}$

In some situations, however, a broad problem-definition can have the opposite effect: it can increase both the probability of an impasse and the time and expense required for mediation by focusing the parties on issues that are unnecessary to the resolution of the narrow issues and that might exacerbate conflict. 112 In addition, broad problem-definition can make parties and lawyers uncomfortable with the process. They may fear the expression of strong emotions and doubt their own abilities to collaborate with the other side and still protect their own interests. 113

In the Computec case, the parties' mutual dependence and need to work together suggest the desirability of a broad problem-definition. One could also imagine, however, that it might be best simply to resolve the narrow issue, so that the disputants could get on with their work. If we change the facts slightly, we could see the possible virtue of a narrow focus. For instance, if the contract had already terminated, if the parties had no interest in future relations, and if they both believed that the matter could best be handled simply by addressing the issue of whether and how much Golden State should

110. See supra Part II.B.; Kressel et al., supra note 26, at 73-77.

111. See BuSH \& FoLGER, supra note 29 passim; Riskin, supra note 17, at 34 .

112. This risk would be reduced, of course, if the mediator followed a facilitative approach to problem-definition.

113. See Marguerite Millhauser, The Unspoken Resistance to Alternative Dispute Resolution, 3 NEG. J. 29, 31 (1987); Riskin, supra note 17. 
pay, a narrow approach might make great sense. (Of course, the danger here is that the person carrying this narrow vision of the dispute does not fully understand the situations of all concerned, and, for that reason, is unaware of the possibilities for future collaboration.)

\section{The Mediator Role Continuum}

a. The Evaluative Approach. - The evaluative mediator, by providing assessments, predictions, or direction, removes some of the decision-making burden from the parties and their lawyers. In some cases, this makes it easier for the parties to reach an agreement. Evaluations by the mediator can give a participant a better understanding of his "Best Alternative to a Negotiated Agreement" (BATNA), ${ }^{114}$ a feeling of vindication, or an enhanced ability to deal with his constituency. If you were Computec's lawyer, for example, and were having trouble educating your client about the weaknesses of its case, you might want a mediator willing to predict credibly what would happen in court. ${ }^{115}$

Yet, in some situations an assessment, prediction, or recommendation can make it more difficult for the parties to reach agreement by impairing a party's faith in the mediator's neutrality ${ }^{116}$ or restricting a party's flexibility. ${ }^{117}$ As Arthur Chaykin of Sprint Corp. has written:

Parties often feel [an evaluation] is what they want, until they get it. Once the "opinion" is given, the parties often feel that the mediator betrayed them. They will feel that the mediator's decision on the merits may have been influenced by perceptions of what they would be willing to swallow, not on the "merits" of the case .... Nevertheless, the parties should understand that once they involve a third party, and allow that "neutral" to give an opinion on the merits, that determination will almost always have a powerful impact on all further negotiations. After all,

114. See FISHER ET Al., supra note 21, at 100.

115. There are ways to address this issue even in a facilitative mediation, of course. The client might be influenced by the mediator's questions about your case and by your responses. It is also possible, in a facilitative mediation, to bring in an outside expert solely to provide an evaluation. A strong need for an outsider's expert opinion on a legal matter might incline you to choose another process, such as early neutral evaluation or non-binding arbitration.

116. See Alhadeff, supra note 63 , at $\S 23: 8$.

117. Professors Peter J.D. Carnevale, Rodney G. Lim, and Mary E. McLaughlin concluded that their survey of mediators showed that mediators tended to use "substantive/pressure" tactics in situations involving hostility and that the use of such tactics in the face of high hostility correlated negatively with settlement. See Peter J.D. Carnevale et al., Contingent Mediator Behavior and Its Effectiveness, in KresSEL \& PRUTT, supra note 28 , at $213,230-35$. 
how could the "prevailing party" take much less than what the mediator recommended? ${ }^{118}$

Moreover, these evaluative techniques decrease the extent of the parties' participation, and thereby may lower the participants' satisfaction with both the process and the outcome. Of course, such techniques also reduce opportunities for change and growth.

In addition, if the parties or lawyers know that the mediator will evaluate, they are less likely to be candid either with their counterparts or with the mediator. When a mediator asks such parties (in private caucus, for example) to analyze the strengths and weaknesses of their own case or to describe their situation and interests, they may be disinclined to respond honestly. ${ }^{119}$ Thus, the prospect that the mediator will render an evaluation can interfere with the parties' coming to understand fully their own and each other's positions and interests, and thereby render the process more adversarial. ${ }^{120}$

b. The Facilitative Approach. - On the one hand, the facilitative approach offers many advantages, particularly if the parties are capable of understanding both sides' interests or developing potential solutions. It can give them and their lawyers a greater feeling of participation and more control over the resolution of the case. They can fine-tune the problem-deinition and any resulting agreement to suit their interests. The facilitative approach also offers greater potential for educating parties about their own and each other's position, interests, and situation. In this way, it can help parties improve their ability to work with others and to understand and improve themselves.

118. Chaykin, supra note 100 , at 65 n.5. There are ways to minimize the effect of evaluation. The parties could agree in advance that the mediator will delay preparing an assessment, prediction, or recommendation - or sharing it with the parties until after they have exhausted opportunities for negotiation or even until both parties agree, during the mediation, that they want such an opinion. See CPR LEGAL Program, Mediation in Action: Resolving a Complex Business Dispute (videotape, 1994).

If we change the facts in Computec slightly, there may be other reasons to avoid an opinion on the legal merits. For instance, if the contract was drafted by the same outside lawyer who would represent Golden State in the mediation, that lawyer might prefer to protect her reputation by avoiding the risk of a contrary opinion. If this lawyer is reasonable, a more facilitative process might more readily influence her to recommend a solution - without admitting that she was wrong.

119. See Alhadeff, supra note 63, at § 23:8; Stephen B. Goldberg, The Mediation of Grievances Under a Collective Bargaining Contract: An Alternative to Arbitration, 77 Nw. U. L. REv. 270, 304-305 (1982).

120. This is especially true in a narrow mediation and as to narrow issues in a broader mediation. 
On the other hand, when participants are not sufficiently knowledgeable or capable of developing proposals or negotiating with one another, the facilitative approach holds certain risks. The participants might fail to recognize relevant issues or interests, to fully develop options, or to reach an agreement that is as "good" - by whatever standards - as they would reach with a more evaluative mediator. In addition, a poorly-conducted facilitative approach might waste a great deal of time if it does not respond to underlying interests either in the process or in the outcome.

\section{B. The Importance of Subject-Matter Expertise}

In selecting a mediator, one would want to consider the relative importance of "subject-matter expertise" as compared to expertise in the mediation process. ${ }^{121}$ "Subject-matter expertise" means substantial understanding of the legal or administrative procedures, customary practices, or technology associated with the dispute. In the Computec case, for instance, a neutral with subject-matter expertise could be familiar with the litigation of computer services contract disputes; with the structure, economics, and customary practices of the savings and loan or computer services industries; with computer technology (especially as related to financial services industries); or with all of these.

The need for subject-matter expertise typically increases in direct proportion to the parties' need for the mediator's evaluations. ${ }^{122}$ In addition, the kind of subject-matter expertise needed depends on the kind of evaluation or direction the parties seek. If they want a prediction about what could happen in court, they might prefer an evaluative mediator with a strong background in related litigation. If they want ideas about how to structure future business relations, perhaps the mediator should understand the relevant industries. If they want suggestions about how to allocate costs, they may need a mediator who understands the relevant technology. If they need help in sorting out interpersonal-relations problems, they would benefit

121. For the results of a survey that polled corporate counsel on this issue, see CPR Fax Poll: Skills Needed for Mediation, Alternatives to the High Cost of LitrGATION, Dec. 1994, at 145.

122. See Chaykin, supra note 100 , at $60,62-64$. On the other hand, some familiarity with law may be essential for mediators of any orientation who work in court mediation programs in which parties often are not represented by lawyers. This knowledge would be necessary, even for a faciliative-broad mediator - if only to onable him to know when to refer parties to a lawyer. See Jacqueline M. Nolan-Haley, Court Mediation and the Search for Justice Through Law, 74 WASH. U. L.Q. 501 (1996). 
from a mediator oriented toward such issues, rather than one inclined to shy away from them. If they want to propose new government regulations, they might wish to retain a mediator who understands administrative law and procedure.

In contrast, to the extent that the parties feel capable of understanding their circumstances and developing potential solutions singly, jointly, or with assistance from outside experts - they might, if they had to choose, prefer a mediator with great skill in the mediation process, even if she lacks subject-matter expertise.

The complexity and importance of a technical issue should influence the nature and extent of the required subject-matter expertise. In almost any mediation, the neutral must at least be able quickly to acquire a minimal level of familiarity with technical matters in order to facilitate discussions or propose areas of inquiry. ${ }^{123}$ But to the extent that other participants have this expertise, the need for the mediator to possess it diminishes. In fact, too much subject-matter expertise could incline some mediators toward a more evaluative role, thereby interfering with the development of creative solutions.

\section{The Importance of Impartiality}

The idea that the mediator should be neutral or impartial both in fact and in appearance - is deeply imbedded in the ethos of mediation, even though observers disagree about the meaning and achievability of the notion. ${ }^{124}$ The need for impartiality increases in direct proportion to the extent to which the mediator will evaluate.

123. See CPR Fax Poll, supra note 121, at 164; Stephen B. Goldberg, Reflections on Negotiated Rulemaking: From Conflict to Consensus, Wash. LAw., SeptJOct. 1994, at 42, 47-48.

Tom Arnold, a prominent intellectual property lawyer and mediator, has written that a mediator must be "literate" about the subject matter, "but once that literacy threshold is passed, the importance of subject matter expertise dissipates very rapidly except in a few narrow areas like computer software, patents, trademarls, antitrust, tax and perhaps bankruptcy." Tom Arnold, 20 Common Errors in Mediation Advocacy, Alternatives to the High Cost of Litigation, May 1995, at 69.

124. See Sydney E. Bernard et al., The Neutral Mediator: Value Dilemmas in Divorce Mediation, 4 MED. Q. 61 (1984); Sara Cobb \& Janet Riflin, Neutrality as a Discursive Practice: The Construction and Transformation of Narratives in Community Mediation, in 11 Studres IN Law, Polrtics AND Socretr 69, 70 (Austin Sarat \& Susan S. Silbey eds., 1991); Sara Cobb \& Janet Rifkin, Practice and Paradox: Deconstructing Neutrality in Mediation, 16 LAW \& Soc. INQUIRY 35 (1991); John Forester \& David Stitzel, Beyond Neutrality: The Possibilities of Activist Mediation in Public Sector Conflicts, 5 NEG. J. 251, 254-57 (1989); Christopher Honeyman, Patterns of Bias in Mediation, 1985 J. DISP. Resol. 141, 148-49; McCrory, supra note 9, at 53-54; Stulberg, supra note 9; Susskind, supra note 9, at 86. 
In other words, the greater the mediator's direct influence on the substantive outcome of the mediation, the greater the risk that one side will suffer as a result of the mediator's biases.

Imagine that you represent Computec and propose mediation to the lawyer representing Golden State. After considering the matter for a few days, she says she is ambivalent but that she would be inclined to agree to mediation if she could be satisfied with the mediator. Eventually, she proposes a neutral who is a lawyer, with substantial practice experience in both the financial services and computer industries, as well as an experienced mediator. She also tells you that the proposed mediator and she were close friends in college and that they occasionally get together for lunch or dinner. You do not know the mediator but are familiar with her fine reputation.

Your response to this proposal likely would depend in part upon your expectation as to the role the mediator would take in the process. If you wanted or expected evaluation, you might worry about this mediator's possible partiality. If you expected facilitation, this mediator might be just what you need, especially since her selection may be the only way to get the case into mediation. Of course, you would want to be certain that the proposed mediator is willing and able to commit to and carry out a facilitative process.

\section{Conclusion}

Mediation seems to encompass a bewildering variety of activities. But many professionals in the field have definite, and often limited, ideas of what mediation is or should be. Accordingly, they often ignore other forms of the practice or argue that they really do not constitute mediation. As a consequence, many organizations and individuals concerned with the mediation process - courts, administrative agencies and other program sponsors, lawyers, and potential mediation participants - make decisions about mediation based on an incomplete understanding of the available choices.

One cause of this situation is the absence of any widely-shared comprehensive method for describing the various approaches to mediation practice. In writing this Article, I mean to provide such a method. My goal is to facilitate clear thinking about processes that are commonly called mediation and fall, at least arguably, within the usual understanding of mediation as negotiation facilitated by an impartial third party. The system can help people understand mediation and make sound decisions about what kind of process they want 
and about selecting, training, and evaluating mediators. ${ }^{125}$ In addition, I hope that individual mediators will use it to reflect on their own work. I believe the framework also could help researchers in seeking to understand how various approaches to mediation correlate with different mediation experiences and outcomes.

I do not hope or expect to have the last word on this topic. I anticipate that commentators will offer ways to improve this system, and I welcome such critiques and the refinement likely to follow from them.

125. Since I first published an abbreviated explanation of the system, see Leonard L. Riskin, Mediator Orientations, Strategies, and Techniques, Alternatrves to the High Cost of Litigation, Sept. 1994, at 111, many teachers and trainers have begun to use it regularly, including some who harbor serious reservations about applying the term "mediation" to activities depicted on certain porions of the grid. In addition, some mediation organizations and mediators already employ the grid to explain mediation - or their version of it - to potential clients. 
APPENDIX

FigURE 4

\section{GRID WITH NW AND SE CORNERS REMOVED}

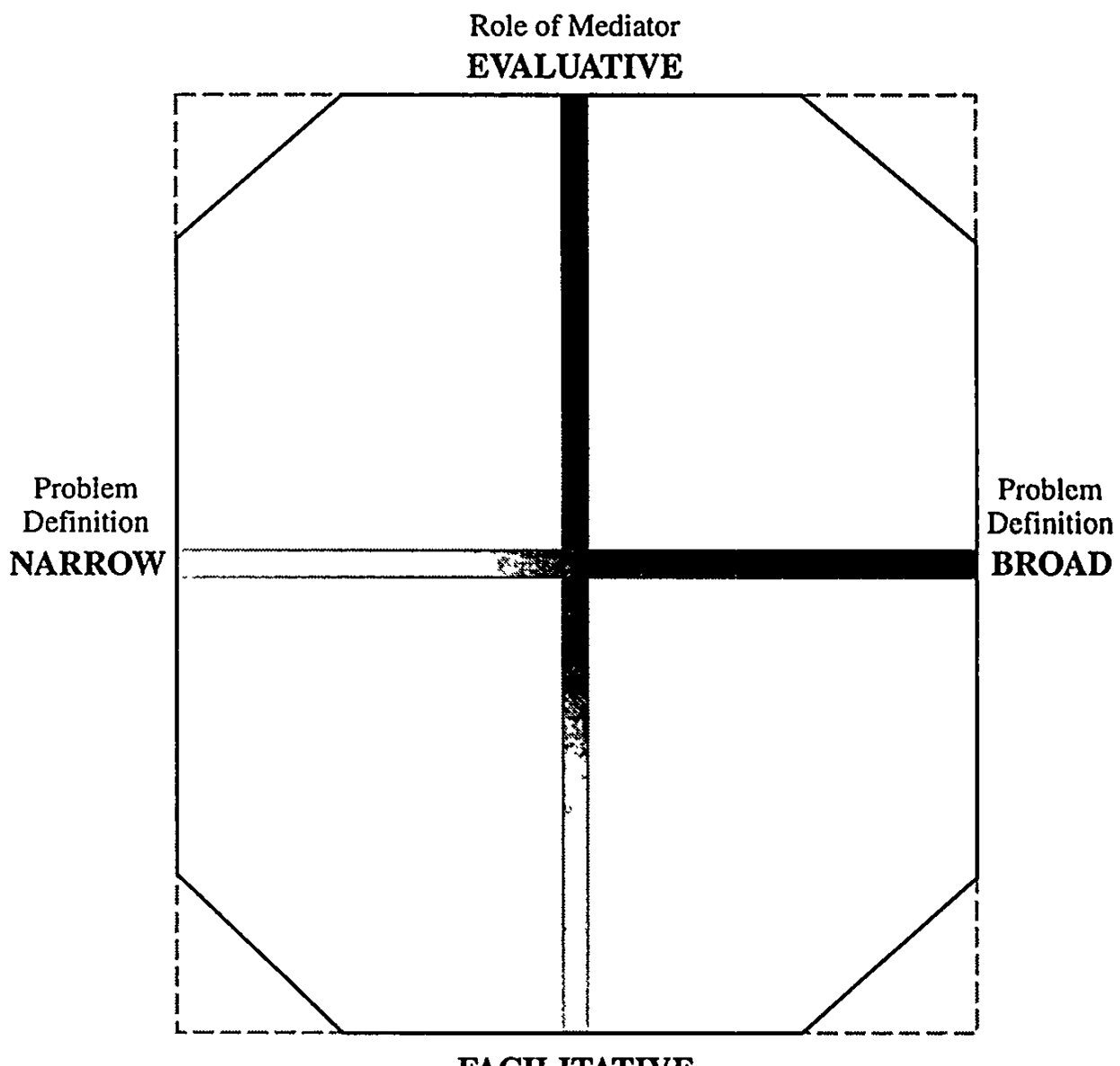

FACILITATIVE

○ 1996 Leonard L. Riskin 
Figure 5

\section{GRID SHOWING CORE AND PERIPHERY OF MEDIATION PRACTICES}

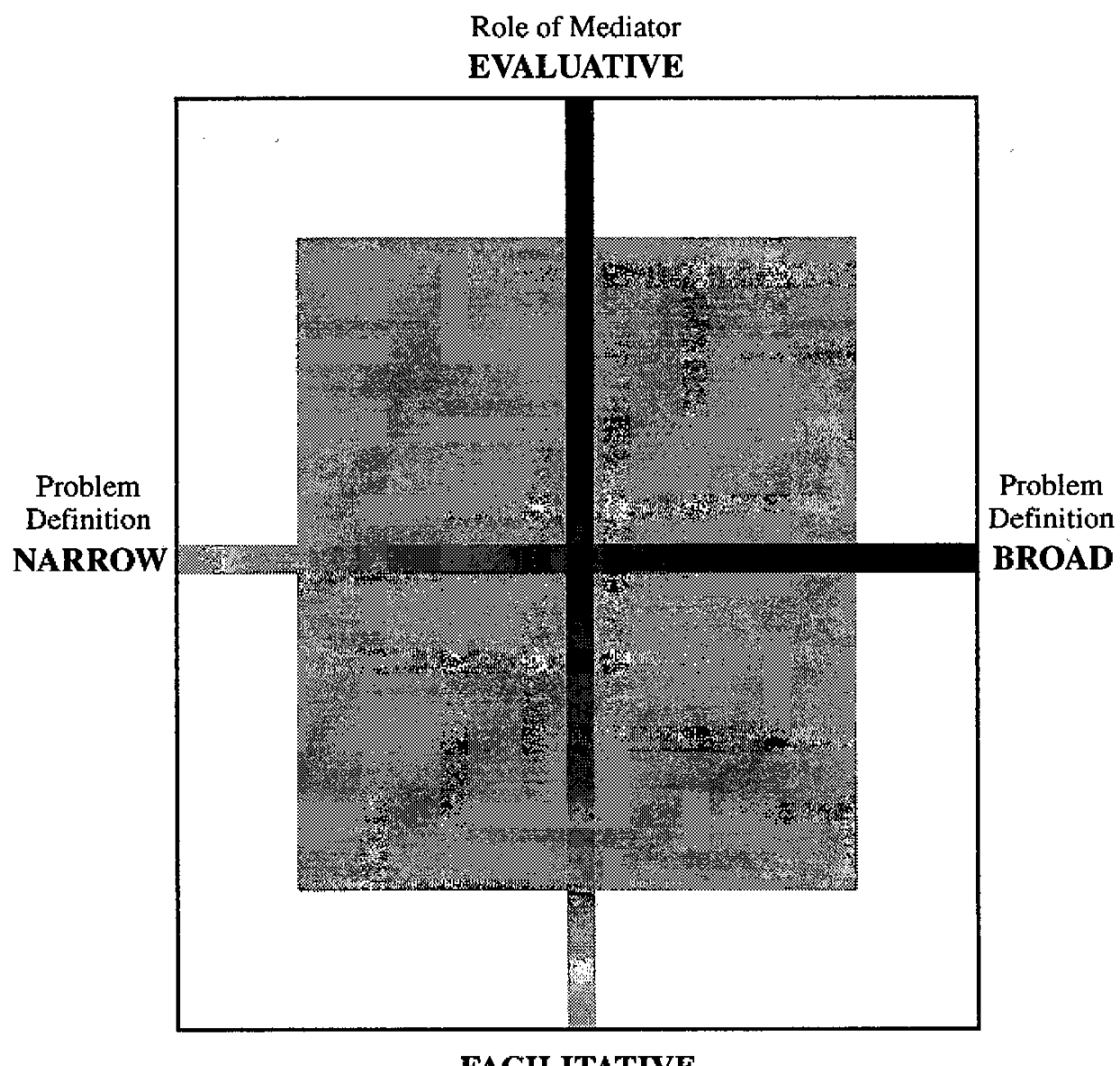

C 1996 Leonard L. Riskin 
